\title{
Bacterial Endophytes: The Hidden Actor in Plant Immune Responses against Biotic Stress
}

\author{
Nadira Oukala ${ }^{1} \mathbb{D}$, Kamel Aissat ${ }^{1,2, *}$ and Victoria Pastor ${ }^{3, *} \mathbb{D}$ \\ 1 Laboratory of Ecological Microbiology, Department of Microbiology, Faculty of Nature and Life Sciences, \\ University of Bejaia, 06000 Bejaia, Algeria; nadira.oukala@univ-bejaia.dz \\ 2 Department of Microbiology and Biochemistry, Faculty of Nature and Life Sciences, University of Batna 2, \\ 05000 Batna, Algeria \\ 3 Metabolic Integration and Cell Signaling Laboratory, Plant Physiology Section, Departamento Ciencias \\ Agrarias y del Medio Natural, Universitat Jaume I, 12071 Castelló de la Plana, Spain \\ * Correspondence: k.aissat@univ-batna2.dz (K.A.); pastorm@uji.es (V.P.)
}

Citation: Oukala, N.; Aissat, K.; Pastor, V. Bacterial Endophytes: The Hidden Actor in Plant Immune Responses against Biotic Stress. Plants 2021, 10, 1012. https://doi.org/ $10.3390 /$ plants10051012

Academic Editor: George Lazarovits

Received: 6 April 2021

Accepted: 13 May 2021

Published: 19 May 2021

Publisher's Note: MDPI stays neutral with regard to jurisdictional claims in published maps and institutional affiliations.

Copyright: (c) 2021 by the authors. Licensee MDPI, Basel, Switzerland. This article is an open access article distributed under the terms and conditions of the Creative Commons Attribution (CC BY) license (https:// creativecommons.org/licenses/by/ $4.0 /)$.

\begin{abstract}
Bacterial endophytes constitute an essential part of the plant microbiome and are described to promote plant health by different mechanisms. The close interaction with the host leads to important changes in the physiology of the plant. Although beneficial bacteria use the same entrance strategies as bacterial pathogens to colonize and enter the inner plant tissues, the host develops strategies to select and allow the entrance to specific genera of bacteria. In addition, endophytes may modify their own genome to adapt or avoid the defense machinery of the host. The present review gives an overview about bacterial endophytes inhabiting the phytosphere, their diversity, and the interaction with the host. Direct and indirect defenses promoted by the plant-endophyte symbiont exert an important role in controlling plant defenses against different stresses, and here, more specifically, is discussed the role against biotic stress. Defenses that should be considered are the emission of volatiles or antibiotic compounds, but also the induction of basal defenses and boosting plant immunity by priming defenses. The primed defenses may encompass pathogenesis-related protein genes (PR family), antioxidant enzymes, or changes in the secondary metabolism.
\end{abstract}

Keywords: priming; endophytic bacteria; ISR; pathogens; signaling

\section{Introduction}

Plant endophytes are described as microorganisms with the capacity to colonize and develop their lifestyle in the inner parts of the plant, including the root, stem, leaf, flowers, and seeds, while not causing apparent damage to the host plant [1]. Normally, endophytes are isolated from surface-sterilized plant tissue and subsequently cultivated in proper medium [2]. However, in recent years, with the development of metagenomics studies, many endophyte communities have been studied through culture-independent approaches such as the sequencing of the 16S rRNA gene and internal transcribed spacer regions (ITS1 and ITS2), the whole genome sequencing, or through shotgun metagenomics studies [3-5].

Endophytic bacteria play an important role to maintain the health of their host, as they can confer tolerance/resistance to the host plants from abiotic and biotic stresses, as well as in increasing plant growth and crop production [6-10]. Plant-endophyte associations have been studied for many years, however, the mechanisms used by plant endophytic bacteria to mitigate the negative effect of different environmental stressors remains unclear. Several studies have shown that plants may recognize and select their specific microbiota to stablish intimate associations $[8,11,12]$. Trade-off for such interaction may be based in the capacity of the plant host to provide niches for the microbial partner, and endophytes may produce helpful metabolites and signals [13,14], which can increase nutrient uptake and promote plant growth [15], induce resistance against pathogens [16-19] and insect herbivores [20], and increase plant tolerance to salinity [21], low temperature [22], heavy 
metals [23], contaminated chemicals [24], and other abiotic factors. Recent publications have added an additional factor and propose to revisit the disease triangle to consider all the effects produced by the endophytes, in terms of disease suppression from an ecological point of view, going beyond the classic studies [25].

To be able to colonize and move through the plant's endosphere, endophytic bacteria should be equipped with specific and necessary traits [26]. Several genomic studies showed differences between endophytes, phyllosphere-, and rhizosphere-colonizing bacteria. Different studies have described endophyte-gene candidates involved in the adaptation of the bacteria to the endosphere $[21,27]$ when comparing the complete genomes of different endophytes. Further studies are needed to explain the role of the selected genes for successful colonization, as well as to identify specialized genes conferring the possibility of endophytic lifestyle [28].

The abilities of bacterial endophytes to protect plants against pathogens occur through direct mechanisms, such as the release of antimicrobial compounds such as siderophores, antibiotics, hydrolytic enzymes, and other secondary metabolites, and indirect mechanisms which are related to the competition with pathogens for space and nutrients and their ability to modulate plant defense responses [2,19,29].

Nowadays, most of the research about bacteria endophytes has been done by establishing a parallelism between their action and the plant growth-promoting bacteria (PGP) present in the rhizosphere. However, differences in the rhizosphere or phyllosphere environment from that of internal plant tissues are gaining attention to explain the benefits of endophytes [28]. This review aims to focus on, and to highlight, the impact of the bacterial endosymbionts on the host leading to plant defense by diverse means, but more specifically on the defensive priming phase, a particular immune state of the plant that allows a faster and stronger response to stress once the threat is present, involving different physiological and biochemical changes, helping the host to resist further attacks. Priming defense is a strategy that allows an enhancement of plant defense with low physiological cost [30]. Considering the intimate contact of bacterial endophytes with the plant inner tissues, the onset of the priming phase is not constricted to a specific moment but starts from the colonization process into the plant tissues. Most studies in endophyte-induced resistance against pathogens and pests are performed in terms of description of the phenotype and defenses that are induced after pathogen or pest attack, but it is necessary to consider the defenses that are orchestrated by the presence of endophytic bacteria and those that change only when the pathogen is present. The difficulty to clarify this question arises from the diversity of the microbial community, the plant species, and the known fact that priming is a phenomenon that depends on the specific interaction between the plant and the pathogen. We hypothesize that deciphering the strategies used in priming defenses induced by endophytic bacteria will be the most interesting for future sustainable strategies in crop biotechnology and biocontrol.

The present revision starts with an overview of the diversity and distribution of plant endophytes, then, how they interact with the host to colonize and enter the inner tissues, and finally, the action of the endophytic bacteria in plant defense as a direct impact of the phytopathogens and the indirect actions that may include priming defenses.

\section{Diversity and Distribution of Bacterial Endophytes}

Bacterial endophytes can be isolated from two different areas known as the phyllosphere (the aboveground part of the plant) and rhizosphere (the belowground part). Each environment harbors different bacterial communities, shaped by the traits of each section. For the belowground, the diversity can be modulated by different factors related to the soil microbial communities and the host factors. The microbiome composition in the root interior is significantly less diverse than the microbiomes in the rhizosphere or in the soil [8]. The number of bacterial cells in the rot internal tissues reaches $10^{4}-10^{8}$ cells per gram of root tissues, while in the rhizosphere, it is around $10^{6}-10^{9}$ bacterial cells per gram [31]. This suggests that roots act as a biological filter, restricting the penetration of mesospheric 
microbes to the plant endosphere [32]. Regarding the phyllosphere, endophytic bacteria are also less diverse than the epiphytic [33], and it has been rated an average of $10^{6}-10^{8}$ cells bacteria per gram of leaf material [34]. The phyllosphere is in continuous contact with the environment, with an estimated bacterial concentration in the atmosphere of $10^{4}$ to $10^{6}$ cells per $\mathrm{m}^{3}$ [35], being an important source of bacteria in contact with the plant surface. Additionally, the plant endophyte population also depends on other physiological stages of the plant [11].

Several reports have described the diversity of bacterial endophytes in multiple plant species, particularly those with agronomical interest [36,37].

The most representative phylum found in plant bacterial endophytes are Proteobacteria (including $\alpha$, and $\gamma$ classes), Firmicutes, and Actinobacteria [2,3]. Others, such as Bacteroidetes, Planctomycetes, Verrucomicrobia, and Acidobacteria, are less commonly reported as endophytes [8]. Among the most representative genera of bacterial endosymbionts, Pseudomonas, Bacillus, Burkholderia, Stenotrophomonas, Micrococcus, Pantoea, Microbacterium, Enterobacter, Azospirillum, and Serratia are the most described in the literature [26,32]. Interestingly, although they have been studied as endosymbionts, they are also commonly found in the rhizosphere, supporting the idea that endophytic microbiome may be a subpopulation of the rhizosphere bacteria [8]. Rarefaction analysis has underpinned that the endophytic bacterial diversity found in the phyllosphere is lower than the rhizosphere [38]. Phyllosphere diversity is also drawn by different traits. While the root is already surrounded by the bulk soil and is in direct contact with diverse microbial communities, the aboveground part is exposed to the changing environment and the colonization process may be relayed in the aerial dispersion of the microorganisms or in the landing vectors that can introduce bacteria directly in leaves or stems. The movement of bacterial endophytes along the whole plant endosphere includes a wide spectrum of possibilities, depending on the manner of transmission, the organ, and sub-environments inside the organs [39]. In tomato plants, Dong et al. (2019) [40] showed that the abundance of endophytes was similar in roots and leaves in tomato plants. How this equal distribution in amount is common in different plant species must be elucidated. On the other hand, a recent study presented results pointing to generalist endophytes colonizing the phyllosphere regardless of the plant species, at least in the same geographical area [41], reaching $98 \%$ of the detected taxa. Most of the bacteria found belonged to the Proteobacteria and Actinobacteria phylum. Overall, the diversity and localization of endophytic bacteria arise as a complex issue that might be joined to more ecological studies to obtain a more complete picture of the defensive and physiological activities of the hosts.

\section{Interaction of Bacterial Endophytes with the Host}

Plant-endophyte interaction has been developed along millions of years of coevolution, allowing bacteria to develop different traits that enable them to colonize the inner part of the plant [8]. Advanced metagenomic studies point to relevant changes in the genome of bacterial endophytes $[3,26]$. For instance, a genomic analysis of the endophytic bacterium Verrucomicrobia showed a reduction in the genome size with respect to other soil bacteria $[40,42]$. This reduction in the genome of the obligate endosymbiotic bacteria presents a strategy of adaptation on hosts for several activities [43] and can be explained by the presence of a large expansion of insertion sequences (IS) in endophyte genomes [44].

Endophyte penetration into their host may be mediated by two different processes, either passive or active. In the belowground area, the passive penetration occurs mostly at the site of emergence of lateral roots or in the lesions created by deleterious organisms [11], whereas active penetration may be achieved through the attachment of bacterial endophyte to the plant cells using their flagellum and via production of several metabolites that help in penetration process. Those metabolites include, mostly, exopolysaccharides (EPS), cell wall degrading enzymes, and many other quorum-sensing molecules [26,45]. The presence of bacterial flagellum may mediate endophytic ability allowing bacteria to move by chemotaxis and attach to plant surfaces [46]. Straub et al. (2013) [47] showed that 
only the endophytic bacteria containing the entire flagella machinery can colonize wheat roots efficiently while flagella-deficient mutant is blocked in colonization abilities. Genes encoding cell wall degrading enzymes, including cellulases, xylanases, cellobiohydrolases, and endoglucanase, were detected in the metagenome of several endophytic bacteria $[43,48]$. For example, the endoglucanases were shown to be crucial for Azoarcus sp. in colonizing rice roots [49], while pectinases secreted by Bradyrhizobium sp. are essential for its entrance and translocation in the intracellular space in the same plant species [50].

Plant microbiota may be classified ranging from pathogenic to beneficial with different levels of interaction such as epiphytic or saprotrophic [14]. A group of these microorganisms exhibit a mutualistic association with most plants, including the obligate biotrophic lifestyle of some of the microorganisms. Interestingly, they can be found in many varieties of plants including those which have an agricultural interest such as rice, wheat, tomato, maize, strawberry, chickpea, [28,51-53], and several wild plants [54,55].

Additionally, several studies suggest that plant genotypes also have a significant influence on the microbiome in the plant endosphere [56,57]. In certain cases, depending on the host plant genotype, the endophytes may have an asymptomatic endophyte lifestyle or pathogenic [58]. For example, Ramularia collo-cygni can switch its mode of action from an asymptomatic endophyte to a harmful pathogenic fungus along the developmental stages of crops [59]. In addition, Mina et al. (2020) [33] showed that each genotype and organ of different olive trees are selective towards the phyllosphere endophytic bacteria, the tree genotype being the first selective trait, and then the organ. Thus, the dependence of the host genotype might shape the endophytic microbes as a general characteristic.

\subsection{Metabolites Implicated in the Interaction of Host-Bacterial Endophyte}

Plant colonization of endophytic bacteria involves multiple events, starting with the crosstalk of signal molecules exchanged between the endophytes and their host [26]. Root exudates constitute an important source of metabolites that act as attractants of beneficial microbes. Among the substrates found in the rhizosphere carbohydrates, lipids, amino acids, phenolics, phytosiderophores, and flavonoids are the most described [60] using these molecules as a carbon source for their development. Interestingly, these molecules can modify bacteria-host interaction by modulating gene expression patterns in the microorganism $[61,62]$. Flavonoids are one of the best described chemoattractants, especially in legume roots with rhizobia [63]. However, these compounds also help nonrhizobial endophytes, such as in the colonization of root in rice by the endophytic bacterium Serratia sp. [64]. Other metabolites promoting the attraction of endophytic bacteria are the citric acid and oxalate, from the tricarboxylic acid flux. Specifically, citric acid in cucumber exudates was demonstrated to recruit Bacillus amyloliquefaciens SQR9, as well as promote biofilm formation [65]. On the other hand, Burkholderia phytofirmans strain defective in oxalate utilization was observed in significantly lower concentration compared to the wild type in both maize and lupine plants secreting different levels of oxalate [66]. Besides, phyllosphere endophytes have easy access to several metabolites, such as carbohydrates and amino acids, among others, but also can access carbon sources derived from plant volatiles such as isoprenes and methanolic compounds that allow microbial populations to develop in the aboveground tissues [51].

\subsection{Perception of Bacterial Endophytes and Modulation of Plant Immune System}

The plant immune system is well defined when describing the plant-pathogen interaction, but when facing bacterial commensalism, the model of immunity is less studied. Bacterial endophytes must circumvent initial plant defenses to colonize the surface of the plant tissue and/or entry into the endosphere. Different approaches have shown that bacterial endophytes, unlike phytopathogens, can emit their microbial-associated molecular patterns (MAMPs) to avoid an overresponse of plant defenses [67]. MAPMs are known to generate different host responses, such as the production of reactive oxygen species (ROS) and phosphorylation cascades, and initiate transcriptional reprogramming and synthesis 
of secondary metabolites, through the MAMP-triggered immunity (MTI). However, when endophytes enter into communication with the plant, these signals might be different. For instance, Trada et al. (2014) [68] showed that the conserved bacterial MAMP flagellin (flg22) can be differently recognized by the plant from two different strains of bacteria, one pathogenic (Bacillus phytofirmans) and the other nonpathogenic (Xanthomonas campestris). It has been discovered that beneficial bacteria Bacillus subtilis produces subtilomycin, an antibiotic peptide, that binds its self-produced flagellin, avoiding strong plant response probably because of a non-full perception of the bacteria [69]. Additionally, the protein secretion system (SS) used by bacteria for introducing their effectors in the plant cell is also different. While pathogenic strains use type III and IV SS to deliver their virulent proteins inducing effector-triggered immunity in plants, endophytic bacteria do not use this SS, or if so, in a very low abundance [8]. Another important factor in perception and signaling in plant defense is the production and regulation of ROS. These ROS might be also controlled by some bacteria by producing antioxidant enzymes such as catalases (CAT), superoxide dismutase (SOD), and glutathione-S-transferases (GSTs), among others, at the transcriptional level $[3,70]$. All these bacterial strategies are framed in the evasion of the plant response by MAMP divergence, by developing variants from the same MAMP, or degradation, by secreting other compounds that can digest somehow their MAPMs [71].

During the establishment of plant-endophyte symbiosis, both actors may modulate the expression of genes related to the colonization and entrance processes $[7,8,72]$. Interestingly, a comparative genomic study revealed that endosphere isolates of P. fluorescens have significantly more metabolic pathways than those isolated from the rhizosphere that can produce more metabolites used for the plant for signaling events [73]. Recently, several works have evidenced the roles of different miRNA during different pathogenic and mutualistic interactions [74-76]. Plants challenged by pathogenic symbionts, most of the miRNAs, appear to act mainly by inducing defensive proteins or targeting detoxification pathways, with the aim of elimination. On the contrary, for the establishment of endophytes, the miRNAs induced in the host during the establishment of symbiotic endophytes target hormone response pathways and innate immune function $[74,75,77]$, reinforcing the plant immunity. A specific example of miRNA during mutualistic interaction includes the miR172c, which promotes nodulation in several plants by suppressing the translation of the ET-inducible transcription factor APETALA2 [78,79]. In general, during the establishment of symbiosis, most pathways targeted by miRNAs for plant defense are turned off, promoting the entrance of the beneficial endophyte [72].

\section{Extension of Plant Immunity by Endophytes}

Benefits derived from the microbiome present in the phyllosphere have been described already in the literature. Recently, two concepts have been defined regarding the modification/amplification of plant immunity due to the microbiome. Considering the holobiome as an entity, the two types of extended immunity that have been proposed are direct and indirect immunity [80].

\subsection{Direct Interactions in the Holobiont}

The high diversity of microorganisms in the phytosphere may influence pathogens independently of the plant immune system. Endophytes may adopt several strategies to attenuate the negative impacts of pathogens and pests on their host [2,28]. Those activities may be achieved by direct inhibition of pathogens since they share similar colonizing patterns and are in intimate contact with plants. Events for direct inhibition of pathogens are mainly mediated by inhibitory allelochemicals including siderophores, antibiotics, cell wall degrading enzymes, volatile organic compounds (VOCs), alkaloids, steroids, quinines, terpenoids, phenols, and flavonoids [81-85] (Table 1), or by a quenching signal of pathogens [86].

Lipopeptides are one of the most important classes of antimicrobial compounds produced by endophytic bacteria. Lipopeptides isolated from Bacillus and Paenibacillus 
are the most studied [87]. Among the Bacillus genera, several Bacillus amyloliquefaciens strains have been reported as relevant producers of lipopeptides [88]. The endosymbiont Pseudomonas viridiflava was reported to also produce antimicrobial compound nominated ecomycins, a lipopeptide containing unusual amino acids including homoserine and $\beta$ hydroxy aspartic acid [89]. In addition to lipopeptides, several endophytic isolates were reported to also produce other antibiotic compounds, such as polyketides (surfactin, bacillomycin, fengycin, iturin, lichenysin, mycosubtilin, plipastatin, pumilacidin) produced by Bacillus subtilis, polymyxins (a cyclic cationic lipopeptide) synthesized by Paenibacillus polymyxa [90], and many other metabolites recently reviewed, such as flavonoids, quinones, alkaloids, phenols, steroids, and terpenoids [91] (Table 1).

Lytic enzymes produced by the endophytes digest a wide variety of polymeric compounds, including chitin, cellulose, proteins, and lipids [8]. One of the actions of plantcolonizing endophytes is the production of enzymes that hydrolyze plant cell walls. These include $\beta$-1,3-glucanase, chitinase, cellulase, and protease [92]. Chitinase mediates the degradation of chitin, which is the major cell wall component of fungus, thus the release of these enzymes may exert a cross-action of defense by altering the integrity of fungal cell wall, compromising the survival of the pathogen. For instance, the chitinase produced by endophytic Streptomyces hygroscopicus were found to inhibit the growth of different strains of fungi or fungus-like species such as Ralstonia solani, Fusarium oxysporum, Alternaria alternata, Aspergillus niger, Aspergillus flavus, Sclerotinia sclerotiorum, Hyaloperonospora parasitica, and Botrytis cinerea [93]. The endophytic strain Bacillus cereus 65 producing chitinase enzymes was showed to protect the cotton seedlings from root disease caused by R. solani [94] (Table 1).

Endophytic bacteria emit VOCs, another group of antimicrobial compounds with a broad-spectrum activity against phytopathogens bacteria, fungi, and nematodes [28,95-99] (Table 1). Sheroan et al. (2016) [96] demonstrated that black pepper-associated endophytic Pseudomonas putida BP25 could inhibit, by volatile emission, the proliferation of different pathogens including fungi and fungi-like species, and plant-parasitic nematode. In addition to the antimicrobial activity, the advantage of VOCs is their ability to facilitate interactions between physically separated microorganisms. VOCs may be emitted in different chemicals forms. Some of the VOCs produced by endophytes processing as antifungal are cited in Table 1.

Alleviation of ethylene (ET) is also a direct action exerted by endophytic bacteria. ET is demonstrated to increase after pathogen or stress appearance [100], and several reports point to an increase of protection in plants when the seeds have been inoculated with bacterial endophytes. This is due to the bacterial production of the enzyme 1-aminocyclopropane-1-carboxylate (ACC), which can cleave the ET into $\alpha$-ketobutyrate and ammonia, thus reducing the presence of this enzyme associated to plant stress and physiological damage [101].

An additional mechanism for direct action against pathogens is the quenching of the quorum sensing (QS) required for the survival of most microbes, including pathogens. The QS is responsible for the regulation of physiological activities such as cell-cell crosstalk, reproduction, biofilm formation, adaptation, mutualism, and pathogenesis [102]. Several endophytes were reported to hamper signaling pathways of phytopathogens by quorum-quenching mechanisms [86,103]. For example, the endophytic bacteria harbored in Cannabis sativa L was reported to disrupt the cell-to-cell communication of Chromobacterium violaceum [103]. Additionally, Stenotrophomonas maltophilia, Pseudomonas aeruginosa, and Rhodococcus corynebacterioides isolated from the xylem of different plant species could degrade the 3-hydroxy palmitic acid methyl ester (3OH-PAME), a QS molecule of $R$. solanacearum, and reduce bacterial wilt in eggplant [104]. 
Table 1. Antimicrobial compounds produced by the bacterial endophytes.

\begin{tabular}{|c|c|c|c|c|c|c|}
\hline & Endophytes & Plant Host Class & Activity & Compounds & Chemical Classes & References \\
\hline \multirow{12}{*}{ : } & Pseudomonas viridiflava & Grass & Antifungal & Ecomycin & Peptide & [89] \\
\hline & B. subtilis 168 & & Antifungal & Bacilysocin & Phospholipid & [105] \\
\hline & B. thuringiensis & & Insecticidal & $\beta$-exotoxin & Polypeptide & [106] \\
\hline & Streptomyces sp. strain NRRL 30562 & Kennedia nigriscans & Antifungal/Antibacterial & Munumbicins A, B, C, and D, & Peptide & [107] \\
\hline & Streptomyces sp. strain NRRL 30566 & Grevillea pteridifolia & Antibacterial & Kakadumycin A & Peptide & [108] \\
\hline & $\begin{array}{l}\text { Verrucosispora maris } \\
\text { AB-18-032 }\end{array}$ & Sonchus oleraceus & Antibacterial & Proximicin & Peptide & [109] \\
\hline & $\begin{array}{c}\text { Streptomyces sp. HK } \\
10595\end{array}$ & Kandelia candel & Antibacterial & Xiamycin B, Indosespine and Sespenine & $\begin{array}{c}\text { Entacyclic } \\
\text { indolosesquiterpine }\end{array}$ & [110] \\
\hline & Streptomyces sp. & $\begin{array}{l}\text { marine mudflat-derived } \\
\text { actinomycete }\end{array}$ & Antibacterial & Harmaomycin & Peptide derivatives & [111] \\
\hline & B. substilis & & Antibacterial & Subtilin & Peptides & [112] \\
\hline & $\begin{array}{l}\text { Bacillus atrophaeus, } \\
\text { Bacillus mojavensis }\end{array}$ & Glycyrrhiza uralensis & Antifungal & $\begin{array}{l}\text { 1,2-bezenedicarboxyl acid, Methyl } \\
\text { ester, Decanodioic acid, bis(2-ehtylhexyl) } \\
\text { ester }\end{array}$ & Polyketides & [113] \\
\hline & $\begin{array}{c}\text { Lysinibacillus, Staphylococcus, } \\
\text { Enterobacter, Pseudomonas, and } \\
\text { Bacillus species }\end{array}$ & Combretum molle & Antibacterial & & & [114] \\
\hline & $\begin{array}{l}\text { Bacillus } \\
\text { subtilis strain 1-L-29 }\end{array}$ & Camellia oleifera & Antifungal & & & [115] \\
\hline
\end{tabular}


Table 1. Cont.

\begin{tabular}{|c|c|c|c|c|c|c|}
\hline & Endophytes & Plant Host Class & Activity & Compounds & Chemical Classes & References \\
\hline \multirow{6}{*}{$\bigcup_{0}^{\infty}$} & Nodulisporium sp. & Myroxylon balsamum & Antifungal & $\begin{array}{l}\text { phenylethyl alcohol. alkyl alcohols alkyl } \\
\text { alcohols (1-butanol-3-methyl, } \\
\text { 1-propanol-2-methyl, 1-pentanol, 1-hexanol, } \\
\text { 1-heptanol, 1-octanol, 1-nonanol }\end{array}$ & $\begin{array}{l}\text { esters, ketones, benzene } \\
\text { derivatives, a terpenoids, } \\
\text { hydrocarbons. }\end{array}$ & [116] \\
\hline & Enterobacter aerogenes & Maize & Antifungal & 2,3-butanediol & & [117] \\
\hline & Pseudomonas putida BP25 & & Antifungal/antiparasitic & & & [96] \\
\hline & Bacillus velezensis ZSY-1, & Chinese catalpa & Antifungal & $\begin{array}{l}\text { 2-tridecanone, pyrazine (2,5-dimethyl), } \\
\text { benzothiazole, and phenol } \\
\text { (4-chloro-3-methyl) }\end{array}$ & $\begin{array}{l}\text { ketones, alcohols, and } \\
\text { alkanes }\end{array}$ & [118] \\
\hline & Bacillus spp. & & Antifungal & $\begin{array}{l}\text { 1-Hexadecanol, Hexacosyl acetate, } \\
\text { Tryphenylphosphine oxide, } \\
\text { 1,3-Propanediol, 2-methyl, dipropanoate, } \\
\text { 1,4-Pentadiene, Hydroxyurea, Decyl } \\
\text { trifluoroacetate, Pentadecane, } \\
\text { 4-Ethyl-1-octyn-3-ol, Tridecane } \\
\text { Benzothiazole, } \\
\text { N,N-Dimethyldodecylamine, 1,3-Butadiene, } \\
\text { Dodecane, 2-Undecanone IR-(+)-a-pinene }\end{array}$ & & [119] \\
\hline & Bacillus subtilis DZSY21 & Eucommia ulmoides & Antifungal & $\begin{array}{l}\text { 2-Methylbutyric acid, 2-heptanone, and } \\
\text { isopentyl acetate }\end{array}$ & & [120] \\
\hline \multirow{6}{*}{ 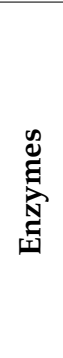 } & B. cereus 65 & mustard & Antifungal & chitinase & & [93] \\
\hline & Lysobacter enzymogenes & Sugar Beet & Antifungal & 1,3-glucanase & & [121] \\
\hline & Streptomyces hygroscopicus & & & chitinase & & [94] \\
\hline & Bacillus pumilus JK-SX001 & Populus & Antifungal & cellulases and protease & & [122] \\
\hline & $\begin{array}{l}\text { Bacillus sp., Micrococcus sp., and } P . \\
\text { polymyxa }\end{array}$ & $\begin{array}{l}\text { Panax ginseng- and } \\
\text { Plectranthus tenuiflorus }\end{array}$ & Antibacterial & $\begin{array}{l}\text { amylase, esterase, lipase, protease, } \\
\text { pectinase, xylanase, and cellulase }\end{array}$ & & [123] \\
\hline & Paenibacillus sp. and Bacillus sp. & Lonicera japonica & & cellulase and pectinase & & [124] \\
\hline
\end{tabular}




\subsection{Indirect Interactions in the Holobiont}

Indirect interactions associated with microbiota comprise the induction of plant defenses. This induction is performed by stimulation of defenses through induced systemic resistance (ISR) or, more accurately proposed in De Kesel et al. 2021 [125], endophyteinduced resistance (E-IR). Each interaction or group of interactions can develop different strategies inducing resistance, depending on the pathosystem.

In general, the priming process depends on different hormonal pathways, [17]. Two types of induced defenses were proposed, ISR and SAR, depending on the hormone implicated and the type of the elicitor [126]. Accordingly, ISR is initiated by rhizobacteria or other non-pathogenic microorganisms, while SAR is induced by pathogens or chemical compounds [127]. The signal transduction pathway of ISR is regulated by the JA/ET pathway and is associated with the expression of the gene DEFENSIN 1.2 (PDF1.2), while SAR is controlled by the SA-dependent signaling pathway and characterized by the expression of genes encoding pathogenesis-related (PR) proteins [128-131]. More recent studies showed that ISR triggered by endophyte and other rhizobacterial strains may be dependent on SA and dependent or not on JA/ET. Niu et al. (2011) [132] explain the dependency on both SAand JA/ET-signaling pathways in the ISR mediated by B. cereus strain AR156. In addition, the treatment of tobacco roots with P. fluorescens CHA0 triggered the accumulation of PR proteins in the leaves induced by SA [133], while in another study, [18], it was shown that the ISR mediated by the root endophytic bacterium Micromonospora against $B$. cinerea is dependent only on the JA/ET pathway (Table 2).

The modulation of signaling and defense components during endophytic colonization may result in the activation of the enhanced resistance. Besides, the crosstalk between endophytic communities and the host plant can activate gene clusters, leading to the synthesis of novel secondary metabolites [28,134-136]. The ability of endophytes in enhancing plant defenses can be assigned to the interaction of the host plant with the bacterial cell themselves or their metabolites [137]. Numerous studies indicated that ISR can be trigged through several compounds produced by endophytes such as phytohormones, lipopeptides, pyocyanin, siderophore, and VOCs [138-141]. ISR triggered by endophytic bacteria can protect the host against a wide range of pathogens including soilborne pathogenic fungi [142-144], biotrophic pathogens [145,146], viruses [147-149], nematodes [150], and insect herbivores [151,152].

The potentiated responses induced by bacterial endophytes include a variety of defense strategies [153]. These strategies include different mechanisms, as illustrated in Figure 1 and discussed below. 


\section{Endophytic bacteria in biological control and inducing plant defenses}

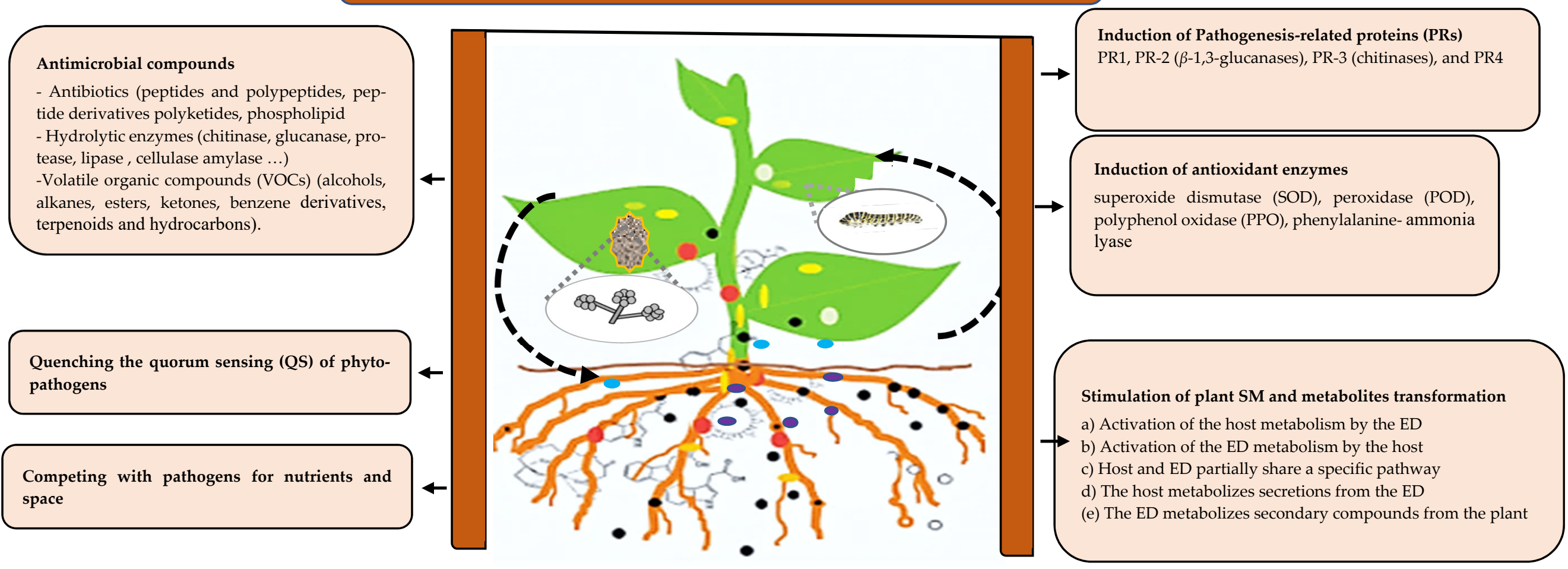

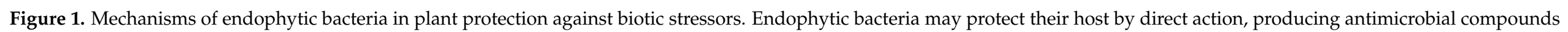

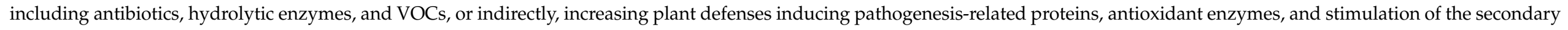
metabolisms of both the host and the bacterial endophyte. ED: endophyte; SM: secondary metabolism. 


\subsubsection{Induction of Pathogenesis-Related Proteins (PRs) and Antioxidant Enzymes}

Pathogenesis-related proteins (PRs) are well-known for their role in acquired resistance and their induction, triggered by necrotic lesions in plants [154,155]. Different studies evidence the ability of some bacterial endophytic strains to also induce PR activity and eventually increase resistance against a wide range of pathogens [156-158]. Among them, $\beta$-1,3-glucanases and chitinases (PR-2 and PR-3 families, respectively) are the best described [143]. Benhamou et al. (1998) [159] showed that the endophytic strain Bacillus pumilus SE34 triggered ISR in tomato plants, with the elaboration of structural barriers, and production of toxic substances such as phenolic compounds and $\beta$-1,3-glucanases. The production of these PR proteins was demonstrated for the disease control exerted by B. amyloliquefaciens strain TB2 on litchi downy blight disease caused by Peronophthora litchi [156]. In addition, in another study, the endophytic actinobacteria isolated from wheat tissues showed an upregulation of PR-1, PR-4, PDF1.2, and HEL defense genes in response to Erwinia carotovora subsp. Carotovora challenge [160]. Moreover, recently, endosymbiotic bacteria Bacillus spp. was reported to produce antifungal lipopeptides (iturin and fengycin) and induce PR genes, including PR-1 and PR-4 in maize [137] (Table 2).

Besides PPRs, several other defense-related enzymes, including antioxidant enzymes SOD, peroxidase (POD), polyphenol oxidase (PPO), phenylalanine, and ammonialyase (PAL), were shown to be important in the induced resistance of several endophytes [146,161-163]. Chandrasekaran and Chun (2016) [146] showed a significant increase in antioxidant enzymes such as SOD, CAT, PPO, and POD dismutase, catalase, peroxidase, and PPO 24 hours after inoculation of the endophytic bacterium B. subtilis in tomato plants. The inoculation of banana plantlet with the endobacterium $S$. marcescens strain UPM39B3 induced the production of host defense enzymes such as peroxidase, PPO, PAL, total soluble phenols, and lignothioglycolic acid, and protected against Fusarium wilt disease [164].

\subsubsection{Stimulation of Plant Secondary Metabolism}

Secondary metabolism of both plant and microsymbiont may be altered due to the interaction. These changes may be produced by several mechanisms. One possibility is that endophyte influences host metabolism by boosting defensive pathways or, in the other way around, plants can manipulate the endophyte metabolism to control its entry and development. Additionally, both plants and bacteria may share different parts of the same pathway, or the host may even metabolize bacterial secretions. In any case, the interplay between host and endophyte is highly controlled by secondary metabolism $[165,166]$.

Phytoalexins are a group of plant antimicrobial molecules with a low molecular weight [131], some of which are terpenoids and flavonoids, among many others. Most studies have been focused on the production of phytoalexins triggered after pathogen perception [167]. On the other hand, some interesting findings revealed that mycorrhizal and rhizobacterial root colonization significantly impact phenolic compounds, alkaloids, terpenoids, and essential oils composition in plants [168-170]. Ramos-Solano et al. (2015) [170] demonstrated that level modifications in flavonoids, phenolics, and anthocyanins were associated with delayed postharvest fungal growth on blackberries treated with the $R h i-$ zobacterium N17.35. Other secondary metabolites, such as the phytoalexin camalexin and glucosinolates, were also quantitatively changed in Arabidopsis plants associated with Pseudomonas fluorescens SS101 [171]. In maize, levels of the benzoxaninones were significantly altered in plants associated with rhizobacterial colonization. Further, Pseudomonas putida KT2440 inoculated in roots was also shown to modify levels of benzoxaninones after three days after inoculation and cause early responses in maize through JA- and ABA-dependent pathways [172].

The abilities of bacterial elicitors such as peptides, glycoprotein, and lipopolysaccharides to trigger plant defense secretion of plant secondary metabolites was reported in several studies. Treatments of the lipopeptide fengycin to potato tuber cells resulted in induced phenylpropanoid pathway metabolism [173]. Moreover, QS molecules of several 
bacterial groups, such as $\mathrm{N}$-acyl-homoserine lactones (AHLs), were also reported to stimulate an accumulation in phenolic compounds, as well as oxylipins and SA in different plant species [174,175].

Endophytes also collaborate with plants in controlling the amount of ROS, thus helping the plants to cope with the toxicity of ROS. This may be explained by the ability of endophytes to produce several metabolites, in particular antioxidants enzymes and phytohormones, as already explained [176,177]. For instance, Festuca arundinacea, Festuca rubra, and Elymus dahuricus contained higher levels of antioxidants and phenolics than endophyte-free plants under different stress conditions [178]. In another study, they found several genes encoding enzymes for ROS scavenging in the genome of several bacterial endophytes, including Enterobacter sp. 638 [179], Gluconacetobacter diazotrophicus [70], and Serratia marcescens RSC-14 [180]. In addition, auxins that could be considered as relevant compounds that mediate plant cell responses to ROS were produced by several endophytes $[2,177,181]$. Indoleacetic acid (IAA) and other indoles could be isolated from different bacterial endophytes including Pseudomonas spp., Ochrobactrum spp., Bacillus spp., Arthrobacter, Enterobacter, and Klebsiella spp. [182-185]. Nevertheless, there is scarce knowledge regarding the role of auxins and auxin-related compounds produced by endophytic microbiomes to support plant growth or defense and influence plant-endophyte interactions.

The endophytic microbiome may also metabolize specific plant-synthesized compounds [186] and may induce the accumulation of other compounds [187]. For example, ET is considered a gaseous hormone that may influence physiological responses to the environment and stress [188-190]. Bacterial endophytes could help to enhance the resistance of plants to stress indirectly by decreasing ET levels, especially during stress, when ET concentration increases $[8,11]$. Some bacterial endophytes use 1-aminocyclopropane1-carboxylate (ACC), the immediate precursor of ET, as a carbon and nitrogen source by producing ACC deaminase, thereby preventing ethylene signaling [191] and indirectly activating other plant defenses only when the stress is present. 
Table 2. Different mechanisms of defenses induced by endophytic bacteria.

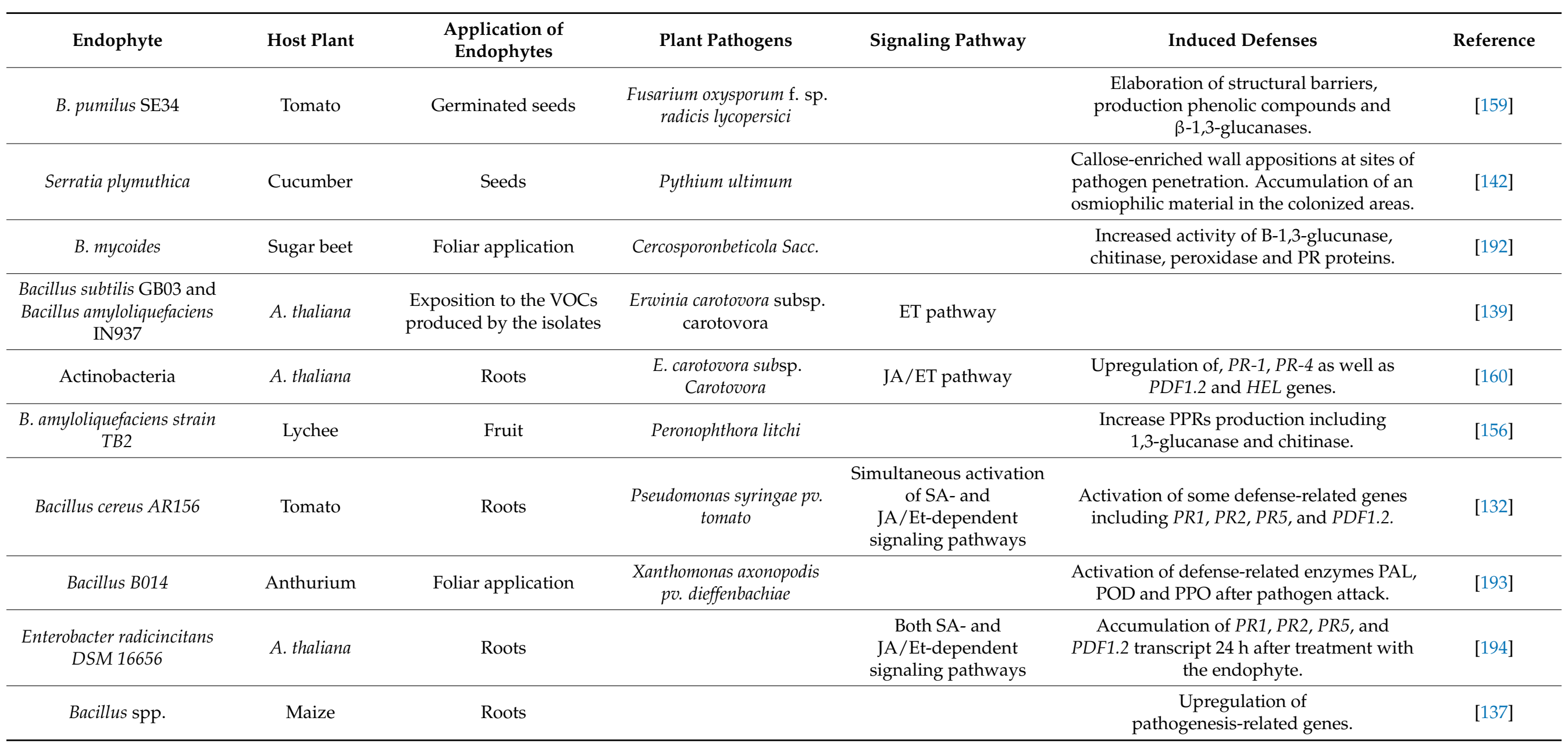


Table 2. Cont.

\begin{tabular}{|c|c|c|c|c|c|c|}
\hline Endophyte & Host Plant & $\begin{array}{l}\text { Application of } \\
\text { Endophytes }\end{array}$ & Plant Pathogens & Signaling Pathway & Induced Defenses & Reference \\
\hline B. amyloliquefaciens $S 499$ & Tomato & Seeds and soil & Botrytis cinerea & & $\begin{array}{l}\text { Induction of lipoxygenase pathway } \\
\text { (accumulation of transcripts of genes } \\
\text { corresponding to the two isoforms, Tom } \\
\text { LOXD and Tom LOXF. }\end{array}$ & [195] \\
\hline $\begin{array}{l}\text { Pseudomonas fluorescens } \\
\text { PICF7 }\end{array}$ & Olive & Roots & Verticillium wilt & & $\begin{array}{c}\text { Activation of olive genes potentially coding } \\
\text { for lipoxygenase 2, catalase, } \\
\text { 1-aminocyclopropane-1-carboxylate } \\
\text { oxidase, and phenylananine } \\
\text { ammonia-lyase. }\end{array}$ & [196] \\
\hline $\begin{array}{l}\text { B. amyloliquefaciens strain } \\
\text { FZB42 }\end{array}$ & Lettuce & Roots & R. solani & & Higher expression of $P D F 1$ and 2. & [197] \\
\hline $\begin{array}{l}\text { B. amyloliquefaciens strain } \\
\text { Blu-v2 }\end{array}$ & Hosta & Filiar application & Spodoptera fruigiperda & & $\begin{array}{l}\text { Production lipopeptides that elicits ISR in } \\
\text { plants against fall armyworms. }\end{array}$ & [151] \\
\hline Micromonospora spp. & Tomato & Roots & B. cinerea & JA/ET pathway & $\begin{array}{l}\text { Induction of JA-regulated defenses (PINII } \\
\text { and LOX A). }\end{array}$ & [18] \\
\hline P. simiae WCS417r & A. thatiana & Roots & Leaf-chewing herbivores & $\mathrm{JA} / \mathrm{ET}$ & $\begin{array}{l}\text { Higher expression of ORA59-branch } \\
\text { respect to the JA-dependent } M Y C 2 \text { branch, } \\
\text { Enhanced synthesis of camalexin and } \\
\text { aliphatic glucosinolates (GLS). }\end{array}$ & [199] \\
\hline Bacillus sp. & Cotton & Soil drench & $\begin{array}{l}\text { Beet armyworm } \\
\text { Spodoptera exigua }\end{array}$ & JA & Accumulation of JA, and JA-related genes. & [200] \\
\hline B. pumilus & Grapevine & Soil drench & P. chlamydospora & & $\begin{array}{l}\text { Enhanced expression of different genes PR } \\
\text { 1, PR 10, chitinase class III, PAL, stilbene } \\
\text { synthase, chalcone synthase, anthranilate } \\
\text { synthase, callose synthase, Glutathione } \\
\text { S-transferase, and b-1,3 glucanase. }\end{array}$ & [201] \\
\hline
\end{tabular}


Table 2. Cont.

\begin{tabular}{|c|c|c|c|c|c|c|}
\hline Endophyte & Host Plant & $\begin{array}{l}\text { Application of } \\
\text { Endophytes }\end{array}$ & Plant Pathogens & Signaling Pathway & Induced Defenses & Reference \\
\hline B. subtilis & Tomato & Soil drench & $\begin{array}{l}\text { Xanthomonas campestris } \\
\text { pv. vesicatoria }\end{array}$ & & $\begin{array}{l}\text { Accumulation of antioxidant enzymes SOD, } \\
\text { CAT, POD, and PPO. }\end{array}$ & [146] \\
\hline $\begin{array}{l}\text { Bacillus amyloliquefaciens } \\
\text { strain MBI600 }\end{array}$ & Tomato & $\begin{array}{l}\text { Drench or foliar } \\
\text { application }\end{array}$ & $\begin{array}{l}\text { Tomato spotted wilt virus } \\
\text { and Potato virus Y }\end{array}$ & SA pathway & $\begin{array}{l}\text { Induction of the SA signaling pathway in } \\
\text { tomato after MBI600 treatment. }\end{array}$ & [148] \\
\hline Azospirillum sp. B510 & Rice & Soil drench & & $\begin{array}{l}\text { ET signaling is required } \\
\text { for endophyte-mediated } \\
\text { ISR }\end{array}$ & $\begin{array}{l}\text { Induces systemic disease resistance in rice } \\
\text { without accompanying defense-related } \\
\text { gene expression. }\end{array}$ & [76] \\
\hline Streptomyces spp. & $\begin{array}{l}\text { Rice, sorghum } \\
\text { and wheat }\end{array}$ & Seedlings & & & $\begin{array}{l}\text { Upregulation of PR10, NPR1, PAL } \\
\text { and LOX2. }\end{array}$ & [202] \\
\hline $\begin{array}{c}\text { Bacillus cereus } \\
\text { Serratia nematodiphila } \\
\text { TLE1.1 }\end{array}$ & Tomato & Seeds & Ralstonia syzigiisub sp. & JA & $\begin{array}{l}\text { Increase JA contained in leaves and roots of } \\
\text { tomato significantly until } 12 \text { days after } \\
\text { pathogen inoculation. }\end{array}$ & [203] \\
\hline
\end{tabular}




\section{Conclusions and Perspective}

Nowadays, plant immunity is prone to be considered in terms of a whole system, including the action and interaction of a complex holobiome, in which plant and microbes in the phytosphere may prepare the final output when facing biotic stress. In the present study, we have revised the actions exerted by bacterial endophytes in promoting plant health Moreover, we would like to attract attention to the function of the bacterial endophytes as actors of the ISR and, more specifically, in priming defenses. It is known that primed defenses generate exceptional protection with low physiological cost in the plant. Although the study around this subject is increasing, the mechanisms involved in the joint action of plant-endophyte against biotic stressors are still ongoing, due to the difficulty in working with one specific endophyte strain separately from others sharing the same niche. Several issues are now open in this new field of research. One of these is the choice of studying the action of one endophyte or the combination of several endophytes (which indeed may be closer to the real situation in nature) in induced resistance against biotic stressors; or, perhaps, isolate one strain that can improve plant immunity in different plant species. This can be considered as a three-way interaction study (endophyte-plant-pathogen/pest), gaining more complexity to the experimental system, since it is necessary to know the specific interaction with the plant as the place where the microbes converge. All the works revised in this publication may send a projection of how to develop future strategies for biocontrol, considering the complex interactions between all players, spanning from plants to endophytes, potential vectors of microbes (such as insects), and the whole microbial community that is in contact with the phytosphere. In addition, endophytes may serve as metabolite producers that may help in techniques of biocontrol or for a more sustainable agriculture. Another question that needs to be elucidated is how to combine plant-growth promotion with priming defenses. A possible link between these two events may focus future research.

Author Contributions: Conceptualization, N.O. and V.P.; methodology, K.A.; software, N.O.; resources, K.A.; writing —original draft preparation, N.O and K.A.; writing — review and editing, V.P.; visualization, K.A.; supervision, V.P.; project administration, V.P.; funding acquisition, V.P. All authors have read and agreed to the published version of the manuscript.

Funding: The funding has been provided from Generalitat Valenciana GV/2018//115 and from the Spanish Ministry of Science, Innovation and Universities RTI2018-094350-B-C33.

Institutional Review Board Statement: Not applicable.

Informed Consent Statement: Not applicable.

Data Availability Statement: Not applicable.

Conflicts of Interest: The authors declare no conflict of interest.

\section{References}

1. Yadav, A.N. Biodiversity and biotechnological applications of host specific endophytic fungi for sustainable agriculture and allied sectors. Acta Sci. Microbiol. 2018, 1, 1-5. [CrossRef]

2. Santoyo, G.; Moreno-Hagelsiebb, G.; Orozco-Mosquedac, M.C.; Glick, B.R. Plant growth-promoting bacterial endophytes. Microbiol. Res. 2016, 183, 92-99. [CrossRef]

3. Sessitsch, A.; Hardoim, P.; Döring, J.; Weilharter, A.; Krause, A.; Woyke, T.; Mitter, B.; Hauberg-Lotte, L.; Friedrich, F.; Rahalkar, M.; et al. Functional characteristics of an endophyte community colonizing rice roots as revealed by metagenomic analysis. Mol. Plant Microbe Interact. 2012, 25, 28-36. [CrossRef]

4. Akinsanya, M.A.; Goha, J.K.; Lima, S.P.; Ting, A.S.Y. Metagenomics study of endophytic bacteria in Aloe vera using nextgeneration technology. Genom. Data 2015, 6, 159-163. [CrossRef]

5. Puri, R.R.; Adachi, F.; Omichi, M.; Saeki, Y.; Yamamoto, A.; Hayashi, S.; Ali, M.A.; Itoh, K. Metagenomic study of endophytic bacterial community of sweet potato (Ipomoea batatas) cultivated in different soil and climatic conditions. World J. Microbiol. Biotechnol. 2019, 35, 176. [CrossRef]

6. Ali, S.; Charles, T.C.; Glick, B.R. Delay of flower senescence by bacterial endophytes expressing 1-aminocyclopropane-1carboxylate deaminase. J. Appl. Microbiol. 2012, 113, 1139-1144. [CrossRef] [PubMed] 
7. Coutinho, B.G.; Licastro, D.; Mendonc-Previato, L.; Cámara, M.; Venturi, V. Plant-influenced gene expression in the rice endophyte Burkholderia kururiensis M130. Mol. Plant-Microbe Interact. 2015, 28, 10-21. [CrossRef] [PubMed]

8. Liu, H.; Carvalhais, L.C.; Crawford, M.; Singh, E.; Dennis, P.G.; Pieterse, C.M.J.; Schenk, P.M. Inner plant values: Diversity, colonization and benefits from endophytic bacteria. Front. Microbiol. 2017, 8, 2552. [CrossRef]

9. Lata, R.; Chowdhury, S.; Gond, S.K.; White, J.F.J. Induction of abiotic stress tolerance in plants by endophytic microbes. Lett. Appl. Microbiol. 2018, 66, 268-276. [CrossRef] [PubMed]

10. Latha, P.; Karthikeyan, M.; Rajeswari, E. Endophytic Bacteria: Prospects and Applications for the Plant Disease Management. Plant Health Biotic Stress India 2019, 50. [CrossRef]

11. Hardoim, P.R.; van Overbeek, L.S.; van Elsas, J.D. Properties of bacterial endophytes and their proposed role in plant growth. Trends Microbiol. 2008, 16, 463-471. [CrossRef] [PubMed]

12. Rashid, S.; Charles, T.C.; Glick, B.R. Isolation and characterization of new plant growth-promoting bacterial endophytes. Appl. Soil Ecol. 2012, 61, 217-224. [CrossRef]

13. Gary, S.; Bryn, D. Bioprospecting for microbial endophytes and their natural products. Microbiol. Mol. Biol. Rev. 2003, 67, 491-502. [CrossRef]

14. Brader, G.; Company, S.; Vescio, K.; Mitter, B.; Trognitz, F.; Ma, L.J.; Sessitsch, A. Ecology and genome insights into plantpathogenic and plant-nonpathogenic endophytes. Annu. Rev. Phytopathol. 2017, 55, 61-83. [CrossRef] [PubMed]

15. Afzal, I.; Shinwari, Z.K.; Sikandar, S.; Shahzad, S. Plant beneficial endophytic bacteria: Mechanisms, diversity, host range and genetic determinants. Microbiol. Res. 2019, 221, 36-49. [CrossRef] [PubMed]

16. Sturz, A.V.; Matheson, B.G. Populations of endophyti bacteria which influence host-resistance to Erwinia-induced bacterial soft rotin potato tubers. Plant Soil. 1996, 184, 265-271. [CrossRef]

17. Pieterse, C.M.J.; Zamioudis, C.; Berendsen, R.L.; Weller, D.M.; Van Wees, S.C.M.; Bakker, P.A.H.M. Induced Systemic Resistance by Beneficial Microbes. Annu. Rev. Phytopathol. 2014, 52, 347-375. [CrossRef] [PubMed]

18. Martínez-Hidalgo, P.; García, J.M.; Pozo, M.J. Induced systemic resistance against Botrytis cinerea by Microspora strains isolated from root nodules. Front. Microbiol. 2015, 6, 922. [CrossRef]

19. Oukala, N.; Pastor-Fernandez, J.; Sanmartín, N.; Aissat, K.; Pastor, V. Endophytic Bacteria from the Sahara Desert Protect Tomato Plants Against Botrytis cinerea Under Different Experimental Conditions. Curr. Microbiol. 2021. [CrossRef]

20. Azevedo, J.L.; Maccheroni, J.W.; Pereira, J.O.; Araújo, W.L. Endophytic microorganisms: A review on insect control and recent advances on tropical plants. Electron. J. Biotechnol. 2000, 3, 40-65. [CrossRef]

21. Ali, S.; Charles, T.C.; Glick, B.R. Amelioration of high salinity stress damage by plant growth-promoting bacterial endophytes that contain ACC deaminase. Plant Physiol. Biochem. 2014, 80, 160-167. [CrossRef]

22. Subramanian, P.; Mageswari, A.; Kim, K.; Lee, Y.; Sa, T. Psychrotolerant endophytic Pseudomonas sp. strains OB155 and OS261 induced chilling resistance in tomato plants (Solanum lycopersicum Mill.) by activation of their antioxidant capacity. Mol. Plant Microbe Interact. 2015, 28, 1073-1081. [CrossRef]

23. Rajkumar, M.; Ae, N.; Freitas, H. Endophytic bacteria and their potential to enhance heavy metal phytoextraction. Chemosphere 2009, 77, 153-160. [CrossRef]

24. Siciliano, S.D.; Fortin, N.; Mihoc, A.; Wisse, G.; Labelle, S.; Beaumier, D. Selection of specific endophytic bacterial genotypes by plants in response to soil contamination. J. Appl. Environ. Microbiol. 2001, 67, 2469-2475. [CrossRef]

25. Dini-Andreote, F. Endophytes: The second layer of plant defense. Trends Plant Sci. 2020, 25, 319-322. [CrossRef]

26. Kandel, S.; Joubert, P.; Doty, S. Bacterial endophyte colonization and distribution within plants. Microorganisms 2017, 5, 77. [CrossRef]

27. Ali, S.; Duan, J.; Charles, T.C.; Glick, B.R. A bioinformatics approach to the determination of genes involved in endophytic behavior in Burkholderia spp. J. Theor. Biol. 2014, 343, 193-198. [CrossRef]

28. Khare, E.; Mishra, J.; Arora, N. Multifaceted Interactions between Endophytes and Plant: Developments and Prospects. Front. Microbiol. 2018, 9, 2732. [CrossRef] [PubMed]

29. Mercado-Blanco, J.; Lugtenberg, B. Biotechnological Applications of Bacterial Endophytes. Curr. Biotechnol. 2014, 3, 60-75. [CrossRef]

30. Martínez-Medina, A.; Flors, V.; Heil, M.; Mauch-Mani, B.; Pieterse, C.M.J.; Pozo, M.J.; Ton, J.; van Dam, N.M.; Conrath, U. Recognizing Plant Defense Priming. Trends Plant Sci. 2016, 21, 818-822. [CrossRef] [PubMed]

31. Bulgarelli, D.; Schlaeppi, K.; Spaepen, S.; Ver Loren van Themaat, E.; Schulze-Lefert, P. Structure and functions of the bacterial microbiota of plants. Annu. Rev. Plant Biol. 2013, 64, 807-838. [CrossRef]

32. Bulgarelli, D.; Rott, M.; Schlaeppi, K.; Ver Loren van Themaat, E.; Ahmadinejad, N.; Assenza, F.; Rauf, P.; Huettel, B.; Reinhardt, R.; Schmelzer, E.; et al. Revealing structure and assembly cues for Arabidopsis root-inhabiting bacterial microbiota. Nature 2012, 488, 91-95. [CrossRef]

33. Mina, D.; Pereira, J.A.; Lino-Neto, T.; Baptista, P. Epiphytic and endophytic bacteria on olive tree phyllosphere: Exploring tissue and cultivar effect. Microb. Ecol. 2020, 80, 145-157. [CrossRef]

34. Remus-Emsermann, M.N.P.; Lücker, S.; Müller, D.B.; Pottchoff, E.; Daims, H.; Vorholt, J.A. Spatial distribution analyses of natuiral phyllosphere-colonizing bacteria on Arabidopsis thaliana revealed by fluorescence in situ hybridization. Environ. Microbiol. 2014, 16, 2329-2340. [CrossRef] 
35. Lighthart, B. Mini-review of the concentration various found in the alfresco atmospheric bacterial populations. Aerobiologia 2000, 16, 7-16. [CrossRef]

36. Hallmann, J.; Quadt-Hallmann, A.; Mahaffee, W.F.; Kloepper, J.W. Bacterial endophytes in agricultural crops. Can. J. Microbiol. 1997, 43, 895-914. [CrossRef]

37. Sturz, A.V.; Nowak, J. Endophytic communities of rhizobacteria and the strategies required to create yield enhancing associations with crops. Appl. Soil Ecol. 2000, 15, 183-190. [CrossRef]

38. Delmotte, N.; Knief, C.; Chaffron, S.; Innerebner, G.; Roschitzki, B.; Sclapbach, R.; von Mering, C.; Vorholt, J.A. Community proteogenomics reveals insights into the physiology of phyllosphere bacteria. Proc. Natl. Acad. Sci. USA 2009, 106, 16428-16433. [CrossRef] [PubMed]

39. Frank, A.C.; Saldierma Guzmán, J.P.; Shay, J.E. Transmission of bacterial endophytes. Microorganisms 2017, 5, 70. [CrossRef] [PubMed]

40. Dong, C.J.; Wang, L.L.; Li, Q.; Shang, Q.M. Bacterial communities in the rhizosphere, phyllosphere and endosphere of tomato plants. PLoS ONE 2019, 14, e223847. [CrossRef] [PubMed]

41. Massoni, J.; Bortfeld-Miller, M.; Jardillier, L.; Salazar, G.; Sunagawa, S.; Vorholt, J.A. Consistent host and organ occupancy of phyllosphere bacteria in a community of wild herbaceous plant species. ISME J. 2020, 14, 245-258. [CrossRef] [PubMed]

42. Brewer, T.; Handley, K.; Carini, P.; Gibert, J.; Fierer, N. Genome reduction in an abundant and ubiquitous soil bacterial lineage. Nat. Microbiol. 2016, 2, 16198. [CrossRef]

43. Hottes, A.K.; Freddolino, P.L.; Khare, A.; Donnell, Z.N.; Liu, J.C.; Tavazoie, S. Bacterial adaptation through loss of function. PLoS Genet. 2013, 9, 1003617. [CrossRef] [PubMed]

44. Song, H.; Hwang, J.; Yi, H.; Ulrich, R.L.; Yu, Y.; Nierman, W.C.; Kim, H.S. The early stage of bacterial genome-reductive evolution in the host. PLoS Pathog. 2010, 6, e1000922. [CrossRef] [PubMed]

45. Pinski, A.; Betekhtin, A.; Hupert-Kocurek, K.; Mur, L.A.J.; Hasterok, R. Defining the genetic basis of plant-endophytic bacteria interactions. Int. J. Mol. Sci. 2019, 20, 1947. [CrossRef] [PubMed]

46. Kumar, A.; Droby, S.; Singh, V.K.; Singh, S.K.; White, J.F. Entry, colonization and distribution of endophytic microorganisms in plants in Microbial Endophytes. Funct. Plant Biol. 2019. [CrossRef]

47. Straub, D.; Rothballer, M.; Hartmann, A.; Ludewig, U. The genome of the endophytic bacterium H. frisingense GSF30(T) identifies diverse strategies in the Herbaspirillum genus to interact with plants. Front. Microbiol. 2013, 4, 168. [CrossRef] [PubMed]

48. Sessitsch, A.; Kuffner, M.; Kidd, P.; Vangronsveld, J.; Wenzel, W.W.; Fallmann, K.; Puschenreiter, M. The role of plant-associated bacteria in the mobilization and phytoextraction of trace elements in contaminated soils. Soil Biol. Biochem. 2013, 60, 182-194. [CrossRef]

49. Reinhold-Hurek, B.; Maes, T.; Gemmer, S.; Van Montagu, M.; Hurek, T. An endoglucanase is involved in infection of rice roots by the not-cellulose metabolizing endophyte Azoarcus sp. strain BH72. Mol. Plant Microbe Interact. 2006, 19, 181-188. [CrossRef] [PubMed]

50. Piromyou, P.; Songwattana, P.; Greetatorn, T.; Okubo, T.; Kakizaki, K.C.; Prakamhang, J.; Tittabutr, P.; Boonkerd, N.; Teaumroong, N.; Minamisawa, K. The Type III secretion system (T3SS) is a determinant for rice-endophyte colonization by non-photosynthetic Bradyrhizobium. Microbes Environ. 2015, 30, 291-300. [CrossRef]

51. Vorholt, J.A. Microbial life in the phyllosphere. Nat. Rev. Microbiol. 2012, 10, 828-840. [CrossRef]

52. Gupta, R.; Anand, G.; Gaur, R.; Yadav, D. Plant-microbiome interactions for sustainable agriculture: A review. Physiol. Mol. Biol. Plants 2021, 27, 165-179. [CrossRef]

53. Verma, P.; Yadav, A.N.; Kumar, V.; Singh, D.P.; Sexena, A.K. Benefecial plant microbes interactions: Biodiversity of microbes from diverse extreme environment and its impact for crop improvement. In Plant Microbe Interactions in Agroecological Perspectives; Singh, D.P., Ed.; Springer: Singapore, 2017; pp. 543-580.

54. Pouget, M. Les Relations Sol-Végétation Dans la Steppe Sud-Algéroise; Orstom: Paris, France, 1980; p. 569.

55. Goudjal, Y.; Toumatia, O.; Yekkoura, A.; Sabaou, N.; Barakate, M.; Mathieu, F.; Zitouni, A. Biocontrol of Rhizoctonia solani damping-off and promotion of tomato plant growth by endophytic actinomycetes isolated from native plants of Algerian Sahara. Microbiol. Res. 2014, 169, 59-65. [CrossRef]

56. Rodriguez-Blanco, A.; Sicardi, M.; Frioni, L. Plant genotype and nitrogen fertilization effects on abundance and diversity of diazotrophic bacteria associated with maize (Zea mays L.). Biol. Fertil. Soils. 2015, 51, 391-402. [CrossRef]

57. Ding, T.; Melcher, U. Influences of plant species, season and location on leaf endophytic bacterial communities of non-cultivated plants. PLoS ONE 2016, 11, e0150895. [CrossRef]

58. Bacon, C.W.; Glenn, A.E.; Yates, I.E. Fusarium verticillioides: Managing the endophytic association with maize for reduced fumonisins accumulation. Toxin Rev. 2008, 27, 411-446. [CrossRef]

59. Walters, D.R.; Havis, N.D.; Oxley, S.J.P. Ramularia collo-cygni: The biology of an emerging pathogen of barley. FEMS Microbiol. Lett. 2008, 279, 1-7. [CrossRef]

60. Badri, D.V.; Vivanco, J.M. Regulation and function of root exudates. Plant Cell Environ. 2009, 32, 666-681. [CrossRef] [PubMed]

61. Mark, G.L.; Dow, J.M.; Kiely, P.D.; Higgins, H.; Haynes, J.; Baysse, C.; Abbas, A.; Foley, T.; Franks, A.; Morrissey, J.; et al. Transcriptome profiling of bacterial responses to root exudates identifies genes involved in microbe-plant interactions. Proc. Natl. Acad. Sci. USA 2005, 102, 17454-17459. [CrossRef] 
62. Yi, Y.; Jong, A.; Frenzel, E.; Kuipers, O.P. Comparative Transcriptomics of Bacillus mycoides Strains in Response to Potato-Root Exudates Reveals Different Genetic Adaptation of Endophytic and Soil Isolates. Front. Microbiol. 2017, 8, 1487. [CrossRef] [PubMed]

63. Arora, N.K.; Mishra, J. Prospecting the roles of metabolites and additives in future bioformulations for sustainable agriculture. Appl. Soil Ecol. 2016, 107, 405-407. [CrossRef]

64. Balachandar, D.; Sandhiya, G.S.; Sugitha, T.C.K.; Kumar, K. Flavonoids and growth hormones influence endophytic colonization and in planta nitrogen fixation by a diazotrophic Serratia sp. in rice. World J. Mic. Biotech. 2006, 22, 707-712. [CrossRef]

65. Zhang, N.; Wang, D.; Liu, Y. Effects of different plant root exudates and their organic acid components on chemotaxis, biofilm formation and colonization by beneficial rhizosphere-associated bacterial strains. Plant Soil 2014, 374, 689-700. [CrossRef]

66. Kost, T.; Stopnisek, N.; Agnoli, K.; Eberl, L.; Weisskopf, L. Oxalotrophy, a widespread trait of plant-associated Burkholderia species, is involved in successful root colonization of lupin and maize by Burkholderia phytofirmans. Front. Microbiol. $2014,4,421$. [CrossRef]

67. Dubey, A.; Malla, M.A.; Kumar, A.; Dayanandan, S.; Khan, M.L. Plant endophytes: Unveiling hidden agenda for bioprospecting toward sustainable agricultur. Crit. Rev. Biotechnol. 2020. [CrossRef] [PubMed]

68. Trdá, L.; Fernandez, O.; Boutrot, F.; Héloir, M.C.; Kelloniemi, J.; Daire, X.; Adrian, M.; Clément, C.; Zipfel, C.; Dorey, S.; et al. The grapevine flagellin receptor VvFLS2 differentially recognizes flagellin-derived epitopes from the endophytic growth-promoting bacterium Burkholderia phytofirmans and plant pathogenic bacteria. New Phytol. 2014, 201, 1371-1384. [CrossRef]

69. Deng, Y.; Chen, H.; Li, C.; Xu, J.; Qi, Q.; Xu, Y.; Zhu, Y.; Zheng, J.; Peng, D.; Ruan, L.; et al. Endophyte Bacillus subtilis evade plant defense by producing lantibiotic subtilomycin to mask self-produced flagellin. Commun. Biol. 2019, 2, 368. [CrossRef]

70. Alquéres, S.; Meneses, C.; Rouws, L.; Rothballer, M.; Baldani, I.; Schmid, M.; Hartmann, A. The bacterial superoxide dismutase and glutathione reductase are crucial for endophytic colonization of rice roots by Gluconacetobacter diazotrophicus PAL5. Mol. Plant Microbe Interact. 2013, 26, 937-945. [CrossRef] [PubMed]

71. Teixeira, P.J.P.L.; Colaianni, N.R.; Fitzpatrick, C.R.; Dangl, J.L. Beyond pathogens: Microbiota interactions with the plant immune system. Curr. Opin. Microb. 2019, 49, 7-17. [CrossRef]

72. Plett, J.M.; Martin, F.M. Know your enemy, embrace your friend: Using omics to understand how plants respond differently to pathogenic and mutualistic microorganisms. Plant J. 2018, 93, 729-746. [CrossRef]

73. Timm, C.M.; Campbell, A.G.; Utturkar, S.M.; Jun, S.R.; Parales, R.E.; Tan, W.A.; Robeson, M.S.; Lu, T.Y.; Jawdy, S.; Brown, S.D.; et al. Metabolic functions of Pseudomonas fluorescens strains from Populus deltoides depend on rhizosphere or endosphere isolation compartment. Front. Microbiol. 2015, 6, 1118. [CrossRef] [PubMed]

74. Formey, D.; Sallet, E.; Lelandais-Briere, C.; Ben, C.; Bustos-Sanmamed, P.; Niebel, A.; Frugier, F.J.; Combier, P.; Debellé, F.; Hartmann, C.; et al. The small RNA diversity from Medicago truncatula roots under biotic interactions evidences the environmental plasticity of the miRNAome. Genome Biol. 2014, 15, 457. [CrossRef] [PubMed]

75. Wu, P.; Wu, Y.; Liu, C.C.; Liu, L.W.; Ma, F.F.; Wu, X.Y.; Wu, M.; Hang, Y.Y.; Chen, J.Q.; Shao, Z.Q.; et al. Identification of arbuscular mycorrhiza (AM)-responsive microRNAs in tomato. Front. Plant Sci. 2016, 7, 429. [CrossRef]

76. Kusajima, M.; Shima, S.; Fujita, M.; Minamisawa, K.; Che, F.-S.; Yamakawa, H.; Nakashita, H. Involvement of ethylene signaling in Azospirillum sp. B510-induced disease resistance in rice. Biosci. Biotechnol. Biochem. 2018, 82, 1522-1526. [CrossRef] [PubMed]

77. Li, Y.; Zhang, Q.; Zhang, J.; Wu, L.; Qi, Y.; Zhou, J.M. Identification of microRNAs involved in pathogen associated molecular pattern-triggered plant innate immunity. Plant Physiol. 2010, 152, 2222-2231. [CrossRef]

78. Wang, Y.; Wang, L.; Zou, Y.; Chen, L.; Cai, Z.; Zhang, S.; Zhao, F.; Tian, Y.; Jiang, Q.; Ferguson, B.J.P.; et al. Soybean miR172c targets the repressive AP2 transcription factor NNC1 to activate ENOD40 expression and regulate nodule initiation. Plant Cell 2014, 6, 4782-4801. [CrossRef]

79. Holt, D.B.; Gupta, V.; Meyer, D.; Abel, N.B.; Andersen, S.U.; Stougaard, J.; Markmann, K. micro RNA 172 (miR172) signals epidermal infection and is expressed in cells primed for bacterial invasion in Lotus japonicus roots and nodules. New Phytol. 2015, 208, 241-256. [CrossRef]

80. Fitzpatrick, C.R.; Salas-González, I.; Conway, J.M.; Finkel, O.M.; Gilbert, S.; Russ, D.; Teixeira, O.M.P.L.; Dangl, J.L. The plant microbiome: From ecology to reductionism and beyond. Annu. Rev. Microbiol. 2020, 74, 81-100. [CrossRef]

81. Gunatilaka, A.L. Natural products from plant-associated microorganisms: Distribution, structural diversity, bioactivity, and implications of their occurrence. J. Nat. Prod. 2006, 69, 509-526. [CrossRef]

82. Yu, H.; Zhang, L.; Li, L.; Zheng, C.; Guo, L.; Li, W.; Sun, P.; Qin, L. Recent developments and future prospects of antimicrobial metabolites produced by endophytes. Microbiol Res. 2010, 165, 437-449. [CrossRef]

83. Brader, G.; Compant, S.; Mitter, B.; Trognitz, F.; Sessitsch, A. Metabolic potential of endophytic bacteria. Curr. Opin. Biotechnol. 2014, 27, 30-37. [CrossRef] [PubMed]

84. Chung, J.H.; Song, G.C.; Ryu, C.M. Sweet scents from good bacteria: Case studies on bacterial volatile compounds for plant growth and immunity. Plant Mol. Biol. 2016, 90, 677-687. [CrossRef] [PubMed]

85. Ek-Ramos, M.J.; Gomez-Flores, R.; Orozco-Flores, A.A.; Rodríguez-Padilla, C.; González-Ochoa, G.; Tamez-Guerra, P. Bioactive Products from Plant-Endophytic Gram-Positive Bacteria. Front. Microbiol. 2019, 10, 463. [CrossRef] [PubMed]

86. Miller, M.B.; Bassler, B.L. Quorum sensing in bacteria. Annu. Rev. Microbiol. 2001, 55, 165-199. [CrossRef] 
87. Villarreal-Delgado, M.F.; Villa-Rodríguez, E.D.; Cira-Chávez, L.A.; Estrada-Alvarado, M.I.; Parra-Cota, F.I.; de los SantosVillalobos, S. The genus bacillus as a biological control agent and its implications in the agricultural biosecurity. Mex. J. Phytopathol. 2018, 6, 95-130. [CrossRef]

88. Ongena, M.; Jacques, P. Bacillus lipopeptides: Versatile weapons for plant disease biocontrol. Trends Microbiol. 2008, 16, 115-125. [CrossRef]

89. Miller, R.V.; Miller, C.M.; Kinney, D.G.; Redgrave, B.; Sears, J.; Condron, M.; Strobel, T. Ecomycins, unique antimycotics from Pseudomonas viridiflava. J. Appl. Microbiol. 1998, 84, 937-944. [CrossRef]

90. Stein, T. Bacillus subtilis antibiotics: Structures, syntheses and specific functions. Mol. Microbiol. 2005, 56, 845-857. [CrossRef]

91. Grady, E.N.; MacDonald, J.; Liu, L.; Richman, A.; Yuan, Z.C. Current knowledge and perspectives of Paenibacillus. Microb. Cell Fact. 2016, 15, 203. [CrossRef]

92. Fadiji, A.E.; Babalola, O.O. Elucidating Mechanisms of Endophytes Used in Plant Protection and Other Bioactivities with multifunctional prospects. Front. BioEng. BioTechnol. 2020, 8, 467. [CrossRef]

93. Haggag, W.M.; Abdallh, E.G. Purification and Characterization of Chitinase Produced by Endophytic Streptomyces hygroscopicus Against Some Phytopathogens. Microbiol. Res. 2012, 2, 145-151. [CrossRef]

94. Pleban, S.; Chernin, L.; Chet, I. Chitinolytic activity of an endophytic strain of Bacillus cereus. Lett. Appl. Microbiol. 1997, 25, 284-288. [CrossRef] [PubMed]

95. Wang, C.; Wang, Z.; Qiao, X.; Li, Z.; Li, F.; Chen, M.; Wang, Y.; Huang, Y.; Cui, H. Antifungal activity of volatile organic compounds from Streptomyces alboflavus TD-1. FEMS Microbiol. Lett. 2013, 341, 45-51. [CrossRef]

96. Sheoran, N.; Valiya Nadakkakath, A.; Munjal, V.; Kundu, A.; Subaharan, K.; Venugopal, V.; Rajamma, S.; Eapen, S.J.; Kumar, A. Genetic analysis of plant endophytic Pseudomonas putida BP25 and chemo-profiling of its antimicrobial volatile organic compounds. Microbiol. Res. 2015, 173, 66-78. [CrossRef]

97. Fernando, W.G.D.; Ramarathnam, R.; Krishnamoorthy, A.S.; Savchuk, S.C. Identification and use of potential bacterial organic antifungal volatiles in biocontrol. Soil Biol. Biochem. 2005, 37, 955-964. [CrossRef]

98. Li, Y.; Mao, Z.C.; Wu, Y.X.; Ho, H.H.; He, Y.Q. Comprehensive volatile organic compounds profiling of Bacillus species with biocontrol properties by head space solid phase microextraction with gas chromatography-mass spectrometry. Biocontrol. Sci. Techn. 2014, 25, 132-143. [CrossRef]

99. Munjal, V.; Nadakkakath, A.V.; Sheoran, N.; Kundu, A.; Venugopal, V.; Subaharan, K.; Rajamma, S.; Eapen, S.J.; Kumar, A. Genotyping and identification of broad spectrum antimicrobial volatiles in black pepper root endophytic biocontrol agent, Bacillus megaterium BP17. Biol. Control. 2016, 92, 66-76. [CrossRef]

100. Van Loon, 1.C.; Geraats, B.P.J.; Linthrost, H.J.M. Ethylen as a modulator of disease resistance in plants. Trends Plant Sci. 2006, 11, 184-191. [CrossRef]

101. Gamalero, E.; Glick, B. Bacterial modulation of plant ethylen levels. Plant Physiol. 2015, 169, 13-22. [CrossRef]

102. Hosni, T.; Moretti, C.; Devescovi, G.; Suarez-Moreno, Z.R.; Fatmi, M.B.; Guarnaccia, C.; Pongor, S.; Onofri, A.; Buonaurio, R.; Venturi, V. Sharing of quorum-sensing signals and role of interspecies communities in a bacterial plant disease. ISME J. 2011, 5, 1857-1870. [CrossRef]

103. Kusari, P.; Kusari, S.; Lamshöft, M.; Sezgin, S.; Spiteller, M.; Kayser, O. Quorum quenching is an antivirulence strategy employed by endophytic bacteria. Appl. Microbiol. Biotechnol. 2014, 98, 7173-7183. [CrossRef] [PubMed]

104. Achari, G.A.; Ramesh, R. Characterization of bacteria degrading 3-hydroxy palmitic acid methyl ester (3OH-PAME), a quorum sensing molecule of Ralstonia solanacearum. Lett. Appl. Microbiol. 2014, 60, 447-455. [CrossRef]

105. Tamehiro, N.; Okamot-Hosova, Y.; Okamoto, S.; Ubukata, M.; Hamada, M.; Naganawa, H.; Ochi, K. Bacilysocin, a novel phospholipid antibiotic produced by Bacillus subtilis 168. Antimicrob. Agents Chemother. 2002, 46, 315-320. [CrossRef]

106. Espinasse, S.; Gohar, M.; Lereclus, D.; Sanchis, V. An ABC transporter from Bacillus thuringiensis is essential for betaexotoxin I production. J. Bacteriol. 2002, 184, 5848-5854. [CrossRef]

107. Castillo, U.F.; Strobel, G.A.; Ford, E.J.; Hess, W.M.; Porter, H.; Jensen, J.B.; Albert, H.; Robison, R.; Condron, M.A.M.; Teplow, D.B.; et al. Munumbicins, wide-spectrum antibiotics produced by Streptomyces NRRL30562, endophytic on Kennedia nigriscans. Microbiology 2002, 148, 2675-2685. [CrossRef]

108. Castillo, U.; Harper, J.K.; Strobel, G.A.; Sears, J.; Alesi, K.; Ford, E.; Hess, W.M.; Porter, H.; Jensen, J.B.; Albert, H.; et al. Kakadumycins, novel antibiotics from Streptomyces sp. NRRL 30566, an endophyte of Grevillea pteridifolia. FEMS Microbiol. Lett. 2003, 224, 183-190. [CrossRef]

109. Fiedler, H.P.; Bruntner, C.; Riedlinger, J.; Bull, A.T.; Knutsen, G.; Goodfellow, M.; Jones, A.; Maldonado, L.; Pathom-aree, W.; Beil, W.; et al. Proximicin A, B and C, novel aminofuran antibiotic and anticancer compounds isolated from marine strains of the actinomycete Verrucosispora. J. Antibiot. 2008, 61, 158-163. [CrossRef] [PubMed]

110. Ding, L.; Maier, A.; Fiebig, H.H.; Lin, W.H.; Hertweck, C. A family of multicyclic indolsesquiterpenes from a bacterial endophyte. Organ. Biomol. Chem. 2011, 9, 4029-4031. [CrossRef] [PubMed]

111. Bae, M.; Chung, B.; Oh, K.B.; Shin, J.; Oh, D.C. Hormaomycins B and C: New antibiotic cyclic depsipeptides from a marine mud flat derived Streptomyces sp. Mar. Drugs 2015, 13, 5187-5200. [CrossRef] [PubMed]

112. Singh, M.; Kumar, A.; Singh, R.; Pandey, K.D. Endophytic bacteria: A new source of bioactive compounds. Biotech 2017, 7, 315. [CrossRef] 
113. Mohamad, A.; Abdalla, O.; Li, L.; Ma, J.; Hatab, S.R.; Xu, L.; Guo, J.W.; Rasulov, B.A.; Liu, Y.H.; Hedlund, B.P.; et al. Evaluation of the antimicrobial activity of endophytic bacterial populations from Chinese traditional medicinal plant licorice and characterization of the bioactive secondary metabolites produced by Bacillus atrophaeus against Verticillium dahliae. Front. Microbiol. 2018, 9, 924. [CrossRef] [PubMed]

114. Diale, M.O.; Ubomba-Jaswa, E.; Serepa-Dlaini, M.H. The antibacterial activity of bacterial endophytes isolated from Combretum molle. Afr. J. Biotechnol. 2018, 17, 255-262. [CrossRef]

115. Xu, J.X.; Li, Z.Y.; Yan, H.; Zhou, G.Y.; Cao, L.X.; Yang, Q.; He, Y.H. Isolation and characterization of Bacillus subtilis strain 1-L-29, an endophytic bacteria from Camellia oleifera with antimicrobial activity and efficient plant-root colonization. PLoS ONE 2020. [CrossRef] [PubMed]

116. Mends, M.T.; Yu, E.; Strobel, G.A.; Riyaz-Ul-Hassan, S.; Booth, E.; Geary, B.; Sears, J.; Taatjes, C.A.; Hadi, M.Z. An Endophytic Nodulisporium sp. Producing Volatile Organic Compounds Having Bioactivity and Fuel Potential. J. Pet. Environ. Biotechnol. 2012, 3, 117. [CrossRef]

117. D'Alessandro, M.; Erb, M.; Ton, J.; Brandenburg, A.; Karlen, D.; Zopfi, J.; Turlings, T.C.J. Volatiles produced by soil-borne endophytic bacteria increase plant pathogen resistance and affect tritrophic interactions. Plant Cell Environ. 2014, 37, 813-826. [CrossRef]

118. Gao, Z.; Zhang, B.; Liu, H.; Han, J.; Zhang, Y. Identification of endophytic Bacillus velezensis ZSY-1 strain and antifungal activity of its volatile compounds against Alternaria solani and Botrytis cinerea. Biol. Control. 2017. [CrossRef]

119. Massawe, V.C.; Hanif, A.; Farzand, A.; Mburu, D.K.; Ochola, S.O.; Wu, L.; Tahir, H.A.S.; Gu, Q.; Wu, H.; Gao, X. Volatile Compounds of Endophytic Bacillus spp. have Biocontrol Activity Against Q, 1 Sclerotinia sclerotiorum. Phytopathology 2018, 1-13. [CrossRef]

120. Xie, S.; Liu, J.; Gu, S.; Chen, X.; Jiang, H.; Ding, T. Antifungal activity of volatile compounds produced by endophytic Bacillus subtilis DZSY21 against Curvularia lunata. Ann. Microbiol. 2020, 70, 2. [CrossRef]

121. Palumbo, J.D.; Yuen, G.Y.; Jochum, C.C.; Tatum, K.; Kobayashi, D.Y. Mutagenesis of beta-1,3-Glucanase Genes in Lysobacter enzymogenes Strain C3 Results in Reduced Biological Control Activity Toward Bipolaris Leaf Spot of Tall Fescue and Pythium Damping-Off of Sugar Beet. Phytopathology 2005, 95, 701-707. [CrossRef]

122. Ren, J.H.; Li, H.; Wanga, Y.F.; Ye, J.R.; Yan, A.Q.; Wua, X.Q. Biocontrol potential of an endophytic Bacillus pumilus JK-SX001 against poplar canker. Biol. Control 2013, 67, 421-430. [CrossRef]

123. El-Deeb, B.; Fayez, K.; Gherbawy, Y. Isolation and characterization of endophytic bacteria from Plectranthus tenuiflorus medicinal plant in Saudi Arabia desert and their antimicrobial activities. J. Plant Interact. 2013, 8, 56-64. [CrossRef]

124. Zhao, L.; Xu, Y.; Lai, X.H.; Shan, C.Z.; Deng Yuliang, J. Screening and characterization of endophytic Bacillus and Paenibacillus strains from medicinal plant Lonicera japonica for use as potential plant growth promoters. Braz. J. Microbiol. 2015, 46, 977-989. [CrossRef]

125. De Kesel, J.; Conrath, U.; Flors, V.; Luna, E.; Mageroy, M.H.; Mauch-Mani, B.; Pastor, V.; Pozo, M.J.; Pieterse, C.M.J.; Ton, J.; et al. The induced resistance lexicon: Do's and don'ts. TIPS 2021. [CrossRef]

126. Pieterse, C.M.J.; Van Wees, S.C.M.; Van Pelt, J.A.; Knoester, M.; Laan, R.; Weisbeek, P.J.; van Loon, L.C. A novel signaling pathway controlling induced systemic resistance in Arabidopsis. Plant Cell 1998, 10, 1571-1580. [CrossRef]

127. Mauch-Mani, B.; Baccelli, I.; Una, E.; Flors, V. Defense priming: An adaptative part of induced resistance. Annu. Rev. Plant Biol. 2017, 68, 485-512. [CrossRef] [PubMed]

128. Ward, E.R.; Uknes, S.J.; Williams, S.C.; Dincher, S.S.; Wiederhold, D.L.; Alexander, D.C.; Ahl-Goy, P.; Métraux, J.P.; Ryals, J.A. Coordinate gene activity in response to agents that induce systemic acquired resistance. Plant Cell 1991, 3, 1085-1094. [CrossRef] [PubMed]

129. Van Loon, L.C.; Van Strien, E.A. The families of pathogenesis-related proteins, their activities, and comparative analysis of PR-1 type proteins. Physiol. Mol. Plant Path. 1999, 55, 85-97. [CrossRef]

130. Van Oosten, V.R.; Bodenhausen, N.; Rymond, P.; Van Pelt, J.A.; van Loon, L.C.; Dicke, M.; Pieterse, C.M. Differential effectiveness of microbially induced resistance against herbivorous insects in Arabidopsis. Mol. Plant Microbe Interact. 2008, 21, 919-930. [CrossRef]

131. Gao, F.K.; Dai, C.C.; Liu, X.Z. Mechanisms of fungal endophytes in plant protection against pathogens. Afr. J. Microbiol. Res. 2010, 4, 1346-1351.

132. Niu, D.D.; Liu, H.X.; Jiang, C.H.; Wang, Y.P.; Wang, Q.Y.; Jin, H.L.; Guo, J.H. The plant growth-promoting rhizobacterium Bacillus cereus AR156 induces systemic resistance in Arabidopsis thaliana by simultaneously activating salicylate- and jasmonate/ethylene-dependent signaling pathways. Mol. Plant Microbe Interact. 2011, 24, 533-542. [CrossRef]

133. Maurhofer, M.; Hase, C.; Meuwly, P.; Metraux, J.P.; Defago, G. Induction of systemic resistance of tobacco to tobacco necrosis virus by the root-colonizing Pseudomonas fluorescens strain $\mathrm{CHAO}$ : Influence of the gacA gene and of pyoverdine production. Phytopathology 1994, 84, 139-146. [CrossRef]

134. Pandey, S.S.; Singh, S.; Babu, C.S.; Shanker, K.; Srivastava, N.K.; Kalra, A. Endophytes of opium poppy differentially modulate host plant productivity and genes for the biosynthetic pathway of benzylisoquinoline alkaloids. Planta 2016, 43, 1097-1114. [CrossRef] 
135. Pandey, S.S.; Singh, S.; Babu, C.S.; Shanker, K.; Srivastava, N.K.; Shukla, A.K. Fungal endophytes of Catharanthus roseus enhance vindoline content by modulating structural and regulatory genes related to terpenoid indole alkaloid biosynthesis. Sci. Rep. 2016, 6, 26583. [CrossRef]

136. Sreekanth, D.; Kristin, I.M.; Brett, A.N. Endophytic fungi from Cathranthus roseus: A potential resource for the discovery of antimicrobial polyketides. Nat. Prod. Chem. Res. 2017, 5, 256. [CrossRef]

137. Gond, S.K.; Bergena, M.S.; Torresa, M.S.; White, J.F. Endophytic Bacillus spp. produce antifungal lipopeptides and induce host defense gene expression in maize. Microbiol. Res. 2015, 17, 79-87. [CrossRef] [PubMed]

138. Audenaert, K.; Pattery, T.; Cornelis, P.; Höfte, M. Induction of systemic resistance to Botrytis cinerea in tomato by Pseudomonas aeruginosa 7NSK2: Role of salicylic acid, pyochelin and pyocyanin. Mol. Plant Microbe Interact. 2002, 15, 1147-1156. [CrossRef] [PubMed]

139. Ryu, C.M.; Farag, M.A.; Hu, C.H.; Reddy, M.S.; Kloepper, J.W.; Paré, P.W. Bacterial volatiles induce systemic resistance in Arabidopsis. Plant Physiol. 2004, 134, 1017-1026. [CrossRef] [PubMed]

140. Schuhegger, R.; Ihring, A.; Gantner, S.; Bahnweg, G.; Knaooe, C.; Vogg, G.; Hutzler, P.; Schmid, M.; Breusegem, F.V.; Eberl, L.; et al. Induction of systemic resistance in tomato by $\mathrm{N}$-acyl-L-homoserine lactone-producing rhizosphere bacteria. Plant Cell Environ. 2006, 29, 909-918. [CrossRef]

141. Pérez-García, A.; Romero, D.; de Vicente, A. Plant protection and growth stimulation by microorganisms: Biotechnological application of Bacilli in agriculture. Curr. Opin. Biotechnol. 2011, 22, 187-193. [CrossRef]

142. Benhamou, N.; Gagné, S.; Quéré, D.L.; Dehbi, L. Bacterial-Mediated Induced Resistance in Cucumber: Beneficial Effect of the Endophytic Bacterium Serratia plymuthica on the Protection against Infection by Pythium ultimum. Biochem. Cell Biol. 2000, 90, 45-56. [CrossRef]

143. Dalal, J.M.; Kulkarni, N.S.; Bodhankar, M.G. Utilization of Indigenous Endophytic Microbes for Induction of Systemic Resistance (ISR) in Soybean (Glycine Max (L) Merril) Against Challenge Inoculation with F. oxysporum. Res. Biotechnol. 2015, 6, 10-25.

144. Alvin, A.; Miller, K.I.; Neilan, B.A. Exploring the potential of endophytes from medicinal plants as sources of antimycobacterial compounds. Microbiol. Res. 2014, 169, 483-495. [CrossRef] [PubMed]

145. Fallahzadeh-Mamaghani, V.; Ahmadzadeh, M.; Sharifi, R. Screening systemic resistance-inducing fluorescent pseudomonads for control of bacterial blight of cotton caused by Xanthomonas campestris pv. malvacearum. Plant Pathol. 2009, 91, 663-670. [CrossRef]

146. Chandrasekaran, M.; Chun, S. Induction of defense related enzymes in tomato (Solanum lycopersicum) plants treated with Bacillus subtilis CBR05 against Xanthomonas campestris pv. Vesicatoria. Biocontrol Sci. Technol. 2016, 26, 1366-1378. [CrossRef]

147. Harish, S.; Kavino, M.; Kumar, N.; Samiyappan, R. Biopriming Banana with Plant Growth-Promoting Endophytic Bacteria Induces Systemic Resistance against Banana bunchy top virus. Acta Hortic. 2009, 828, 30. [CrossRef]

148. Beris, D.; Theologidis, I.; Skandalis, N.; Vassilakos, N. Bacillus amyloliquefaciens strain MBI600 induces salicylic acid dependent resistance in tomato plants against Tomato spotted wilt virus and Potato virus Y. Sci. Rep. 2018, 8, 10320. [CrossRef]

149. Manohar Jebakumar, R.; Selvarajan, R. Biopriming of microprapagated banana plants at pre- or post-BBTV inoculation stage with rhizosphere and endophytic bacteria determines their ability to induce systemic resistance against BBTV in cultivar Grand Naine. Biocontrol Sci. Technol. 2018, 28, 1074-1090. [CrossRef]

150. Munif, A.; Hallmann, J.; Sicora, R.A. Induced systemic resistance of selected endophytic bacteria against Meloidogyne incognita on tomato. Meded. Rijksuniv. Gent. Fak. Landbouwkd. Toegep. Biol. Wet. 2001, 66, 663-669.

151. Li, H.; Soares, M.A.; Torres, M.S.; Bergen, M.; White, J.F., Jr. Endophytic bacterium, Bacillus amyloliquefaciens, enhances ornamental hosta resistance to diseases and insect pests. J. Plant Interact. 2015, 10, 224-229. [CrossRef]

152. Rashid, H.O.; Chung, Y.R. Induction of Systemic Resistance against Insect Herbivores in Plants by Beneficial Soil Microbes. Front. Plant Sci. 2017, 8, 1816. [CrossRef] [PubMed]

153. Singh, M.; Srivastava, M.; Kumar, A.; Singh, A.K.; Pandey, K.D. Endophytic bacteria in plant disease management in Microbial Endophytes: Prospects for Sustainable Agriculture. Woodhead Publ. Ser. Food Sci. Technol. Nutr. 2020, 61-89. [CrossRef]

154. Delaney, T.P. Genetic dissection of acquired resistance to disease. Plant Physiol. 1997, 113, 5-12. [CrossRef] [PubMed]

155. Golshani, F.; Fakheri, B.A.; Behshad, E.; Vashvaei, R.M. PRs proteins and their mechanism in plants. Biol. Forum Int. J. 2015, 7, 477-495.

156. Cai, X.Q.; Lin, N.; Chen, W.; Hu, F.P. Control effects on litchi downy blight disease by endophytic bacterial strain Tb2 and its pathogenesis-related proteins. Acta Hortic. 2010, 863, 631-636. [CrossRef]

157. Nie, P.; Li, X.; Wang, S.; Guo, J.; Zhao, H.; Niu, D. Induced systemic resistance against Botrytis cinerea by Bacillus cereus AR156 through a JA/ET- and NPR1- dependent signaling pathway and activates PAMP-triggered immunity in Arabidopsis. Front. Plant Sci. 2017, 8, 238. [CrossRef] [PubMed]

158. Mishra, A.; Singh, S.P.; Mahfooz, S.; Singh, S.P.; Bhattacharya, A.; Mishra, N.; Nautiyal, C.S. Endophyte-Mediated Modulation of Defense-Related Genes and Systemic Resistance in Withania somnifera (L.) Dunal under Alternaria alternata Stress. Appl. Environ. Microbiol. 2018, 84, 8. [CrossRef] [PubMed]

159. Benhamou, N.; Kloepper, J.W.; Tuzun, S. Induction of resistance against Fusarium wilt of tomato by combination of chitosan with an endophytic bacterial strain: Ultrastructure and cytochemistry of the host response. Planta 1998, 204, 153-168. [CrossRef]

160. Conn, V.M.; Walker, A.R.; Franco, C.M.M. Endophytic Actinobacteria Induce Defense Pathways. Mol. Plant Microbe Interact. 2008, 21, 208-218. [CrossRef] 
161. Karthikeyan, M.; Radhika, K.; Mathiyazhagan, S.; Bhaskaran, R.; Samiyappan, R.; Velazhahan, R. Induction of phenolics and defense related enzymes in coconut (Cocos nucifera L.) roots treated with biocontrol agents. Braz. J. Plant Physiol. 2006, 18, 367-377. [CrossRef]

162. Gajanayaka, G.M.D.R.; Prasannath, K.; De Costa, D.M. Variation of chitinase and $\beta-1,3$ glucanase activities in tomato and chilli tissues grown under different crop management practices and agroecological regions. In Proceedings of the Peradeniya University International Research Sessions, Sri Lanka, Jaffna, 4-5 July 2014; Volume 18, p. 519.

163. Prasannath, K.; De Costa, D.M. Induction of peroxidase activity in tomato leaf tissues treated with two crop management systems across a temperature gradient. In Proceedings of the International Conference on Dry Zone Agriculture 2015; Faculty of Agriculture, University of Jaffna: Jaffna, Sri Lanka, 2015; pp. 34-35.

164. Ting, A.S.Y.; Meon, S.; Kadir, J.; Radu, S.; Singh, G. Induction of host defense enzymes by the endophytic bacterium Serratia marcescens, in banana plantlets. Int. J. Pest Manag. 2010, 56, 183-188. [CrossRef]

165. Ludwig-Meuller, J. Plants and endophytes: Equal partners in secondary metabolite production? Biotechnol. Lett. 2015, 37, 1325-1334. [CrossRef]

166. Ogbe, A.A.; Finnie, J.F.; Van Staden, J. The role of endophytes in secondary metabolites accumulation in medicinal plants under abiotic stress. S. Afr. J. Bot. 2020, 8, 46. [CrossRef]

167. Pedras, M.S.C.; Zheng, Q.-A.; Gadagi, R.S.; Rimmer, S.R. Phytoalexins and polar metabolites from the oil seeds canola and rapeseed: Differential metabolic responses to the biotroph Albugo candida and to abiotic stress. Phytochemistry 2008, 69, 894-910. [CrossRef]

168. Toussaint, J.P.; Smith, F.A.; Smith, S.E. Arbuscular mycorrhizal fungi can induce the production of phytochemicals in sweet basil irrespective of phosphorus nutrition. Mycorrhiza 2007, 17, 291-297. [CrossRef]

169. Araim, G.; Saleem, A.; Arnason John, T.; Charest, C. Root colonization by an Arbuscular Mycorrhizal (AM) fungus increases growth and secondary metabolism of purple coneflower, Echinacea purpurea (L.) Moench. J. Agric. Food Chem. 2009, 57, $2255-2258$. [CrossRef]

170. Ramos-Solano, B.; Algar, E.; Gutierrez-Mañero, F.J.; Bonilla, A.; Lucas, J.A.; García-Seco, D. Bacterial bioeffectors delay postharvest fungal growth and modify total phenolics, flavonoids and anthocyanins in blackberries. LWT Food Sci. Technol. 2015, 61, 437-443. [CrossRef]

171. van de Mortel, J.E.; Vos, R.C.H.; De Dekkers, E.; Pineda, A.; Guillod, L.; Bouwmeester, K.; van Loon, J.J.A.; Dicke, M.; Raaijmakers, J.M. Metabolic and transcriptomic changes induced in Arabidopsis by the rhizobacterium Pseudomonas. Plant Physiol. 2012, 160, 2173-2188. [CrossRef]

172. Planchamp, C.; Glauser, G.; Mauch-Mani, B. Root inoculation with Pseudomonas putida KT2440 induces transcriptional and metabolic changes and systemic resistance in maize plants. Front. Plant Sci. 2014, 5, 719. [CrossRef] [PubMed]

173. Ongena, M.; Jacques, P.; Touré, Y.; Destain, J.; Jabrane, A. Involvement of fengycin-type lipopeptides in the multifaceted biocontrol potential of Bacillus subtilis. Appl. Microbiol. Biotechnol. 2005, 69, 29-38. [CrossRef] [PubMed]

174. Schenk, S.T.; Hernández-reyes, C.; Samans, B.; Stein, E.; Neumann, C.; Schikora, M.; Reichelt, M.; Mithöfer, A.; Becker, A.; Kogel, K.H.; et al. N-acyl-homoserine lactone primes plants for cell wall reinforcement and induces resistance to bacterial pathogens via the salicylic acid / oxylipin pathway. Plant Cell 2014, 26, 2708-2723. [CrossRef] [PubMed]

175. Schikora, A. Beneficial effects of bacteria-plant communication based on quorum sensing molecules of the $\mathrm{N}$-acyl homoserine lactone group. Plant Methods 2016, 90, 605-612. [CrossRef] [PubMed]

176. Priti, V.; Ramesha, B.T.; Singh, S.; Ravikanth, G.; Ganeshaiah, K.N.; Suryanarayanan, T.S.; Uma Shaanker, R. How promising are endophytic fungi as alternative sources of plant secondary metabolites. Curr. Sci. 2009, 97, 477-478.

177. Torres, M.S.; White, J.F., Jr.; Zhang, X.; Hinton, D.M.; Bacon, C.W. Endophyte mediated adjustments in host morphology and physiology and effects on host fitness traits in grasses. Fungal Ecol. 2012, 5, 322-330. [CrossRef]

178. Zhou, F.; Gao, Y.B.; Ma, W.J. Effects of phosphorus deficiency on growth of perennial rye grass fungal endophyte symbiont and phenolic content in root. Plant Physiol. Commun. 2003, 39, 321-325.

179. Taghavi, S.; van der Lelie, D.; Hoffman, A.; Zhang, Y.B.; Walla, M.D.; Vangronsveld, J.L.; Newman, S. Monchy. Genome sequence of the plant growth promoting endophytic bacterium Enterobacter sp. 638. PLoS Genet. 2010, 6, e1000943. [CrossRef]

180. Khan, A.R.; Park, G.S.; Asaf, S.; Hong, S.J.; Jung, B.K.; Shin, J.H. Complete genome analysis of Serratia marcescens RSC-14: A plant growth-promoting bacterium that alleviates cadmium stress in host plants. PLoS ONE 2017, 12, e0171534. [CrossRef]

181. Pasternak, T.; Potters, G.; Caubergs, R.; Jansen, M.A. Complementary interactions between oxidative stress and auxins control plant growth responses at plant, organ, and cellular level. J. Exp. Bot. 2005, 56, 1991-2001. [CrossRef]

182. Yue, C.C.; Miller, J.; White, J.; Richardson, M. Isolation and characterization of fungal inhibitors from Epichloe festucae. J. Agric. Food Chem. 2000, 48, 4687-4692. [CrossRef]

183. Piccoli, P.; Travaglia, C.; Cohen, A.; Sosa, L.; Cornejo, P.; Masuelli, R.; Bottini, R. An endophytic bacterium isolated from roots of the halophyte Prosopis strombulifera produces ABA, IAA, gibberellins A1 and A3 and jasmonic acid in chemically-defined culture medium. Plant Growth Regul. 2011, 64, 207-210. [CrossRef]

184. de Santi Ferrara, F.I.; Oliveira, Z.M.; Gonzales, H.H.S.; Floh, E.I.S.; Barbosa, H.R. Endophytic and rhizospheric enterobacteria isolated from sugar cane have different potentials for producing plant growth-promoting substances. Plant Soil. 2012, 353, 409-417. [CrossRef] 
185. Mishra, S.K.; Khan, M.H.; Misra, S.; Dixit, K.V.; Khare, P.; Srivastava, S.; Chauhan, P.S. Characterisation of Pseudomonas spp. and Ochrobactrum sp. isolated from volcanic soil. Antonie Van Leeuwenhoek 2017, 110, 253-270. [CrossRef] [PubMed]

186. Fu, Y.; Yin, Z.H.; Yin, C.Y. Biotransformation of ginsenoside Rb1 to ginsenoside Rg3 by endophytic bacterium Burkholderia sp. GE 17_7 isolated from Panax ginseng. J. Appl. Microbiol. 2017, 122, 1579-1585. [CrossRef]

187. Li, J.; Zhao, G.Z.; Varma, A.; Qin, S.; Xiong, Z.; Huang, H.Y.; Li, W.J. An endophytic Pseudonocardia species induces the production of artemisinin in Artemisia annua. PLoS ONE 2012, 7, e51410. [CrossRef] [PubMed]

188. Arc, E.; Sechet, J.; Corbineau, F.; Rajjou, L.; Marion-Poll, A. ABA crosstalk with ethylene and nitric oxide in seed dormancy and germination. Front. Plant Sci. 2013, 4, 63. [CrossRef]

189. Bakshi, A.; Shemansky, J.M.; Chang, C.; Binder, B.M. History of research on the plant hormone ethylene. J. Plant Growth Regul. 2015, 34, 809-827. [CrossRef]

190. Wei, L.; Deng, X.G.; Zhu, T.; Zheng, T.; Li, P.X.; Wu, J.Q.; Lin, H.H. Ethylene is involved in brassinosteroids induced alternative respiratory pathway in cucumber (Cucumis sativus L.) seedlings response to abiotic stress. Front. Plant Sci. 2015, 6, 982. [CrossRef] [PubMed]

191. Hardoim, P.R.; van Overbeek, L.S.; Berg, G.; Pirttilä, A.M.; Compant, S.; Campisano, A.; Döring, M.; Sessitsch, A. The hidden world within Plants: Ecological and evolutionary considerations for defining functioning of microbial endophytes. Microbiol. Mol. Biol. Rev. 2015, 79, 293-320. [CrossRef] [PubMed]

192. Bargabus, R.L.; Zidack, N.K.; Shewood, J.E.; Jacobsen, B.J. C haracterization of systemic resistance in sugar beet elicited by a non-pathogenic, phyllosphere-colonizing Bacillus mycoides, biological control agent. Physiol. Mol. Plant Path. 2002, 61, 289-298. [CrossRef]

193. Li, S.B.; Fang, M.; Zhou, R.C.; Huang, J. Characterization and evaluation of the endophyte Bacillus B014 as a potential biocontrol agent for the control of Xanthomonas axonopodis pv. dieffenbachiae-Induced blight of Anthurium. Biol. Control 2012, 63, 9-16. [CrossRef]

194. Brock, A.K.; Berger, B.; Mewis, I.; Ruppel, S. Impact of the PGPB Enterobacter radicincitans DSM 16656 on Growth, Glucosinolate Profile, and Immune Responses of Arabidopsis thaliana. Microb. Ecol. 2013, 65, 661-670. [CrossRef]

195. Cawoy, H.; Mariutto, M.; Henry, G.; Fisher, C.; Vasilyeva, N.; Thonart, P.; Dommes, J.; Ongena, M. Plant defense stimulation by natural isolates of Bacillus depends on efficient surfactin production. Mol. Plant Microbe Interact. 2014, 27, 87-100. [CrossRef]

196. Gómez-Lama Cabanás, C.; Schilirò, E.; Valverde-Corredor, A.; Mercado-Blanco, J. The biocontrol endophytic bacterium Pseudomonas fluorescens PICF7 induces systemic defense responses in aerial tissues upon colonization of olive roots. Front. Microbiol. 2014, 5, 427. [CrossRef]

197. Chowdhury, S.P.; Uhl, J.; Grosch, R.; Alquéres, S.; Pittroff, S.; Dietel, K.; Schmitt-Kopplin, P.; Borriss, R.; Hartmann, A. Cyclic lipopeptides of Bacillus amyloliquefaciens subsp. Plantarum colonizing the lettuce rhizosphere enhance plant defense responses toward the bottom rot pathogen Rhizoctonia solani. Mol. Plant Microbe Interact. 2015, 28, 984-995. [CrossRef]

198. Pangesti, N.; Pineda, A.; Dicke, M.; Van Loon, J.J.A. Variation in plant-mediated interactions between rhizobacteria and caterpillars: Potential role of soil composition. Plant Biol. 2015, 17, 474-483. [CrossRef]

199. Pangesti, N.; Reichelt, M.; van de Mortel, J.E.; Kapsomenou, E.; Gershenzon, J.; van Loon, J.J.; Dicke, M.; Pineda, A. Jasmonic acid and ethylene signaling pathways regulate glucosinolate levels in plants during rhizobacteria-induced systemic resistance against a leaf-chewing herbivore. J. Chem. Ecol. 2016, 42, 1212-1225. [CrossRef] [PubMed]

200. Zebelo, S.; Song, Y.; Kloepper, J.W.; Fadamiro, H. Rhizobacteria activates (C)-d-cadinene synthase genes and induces systemic resistance in cotton against beet armyworm (Spodoptera exigua). Plant Cell Environ. 2016, 39, 935-943. [CrossRef]

201. Haidar, R.; Roudet, J.; Bonnard, O.; Dufour, M.C.; Corio-Costet, M.F.; Fert, M.; Gautier, T.; Deschamps, A.; Fermaud, M. Screening and modes of action of antagonistic bacteria to control the fungal pathogen Phaeomoniella chlamydospora involved in grapevine trunk diseases. Microbiol. Res. 2016, 192, 172-184. [CrossRef] [PubMed]

202. Patel, J.K.; Madaan, S.; Archana, G. Antibiotic producing endophytic Streptomyces spp. colonize above-ground plant parts and promote shoot growth in multiple healthy and pathogen challenged cereal crops. Microbiol. Res. 2018, 215, 36-45. [CrossRef] [PubMed]

203. Yanti, Y.; Warnita; Reflin. Involvement of Jasmonic Acid in the Induced Systemic Resistance of Tomato against Ralstonia syzigiisub sp. indonesiensis by Indigenous Endophyte Bacteria. In Proceedings of the 6th International Conference on Sustainable Agriculture, Food and Energy, Earth and Environmental Science, Manila, Philippines, 18-21 October 2018; IOP Publishing: Bristol, UK, 2019; Volume 347, p. 012024. [CrossRef] 